Article

\title{
Polymer-Functionalized Magnetic Nanoparticles: Synthesis, Characterization, and Methylene Blue Adsorption
}

\author{
Xinyu Zheng ${ }^{1}$, Huaili Zheng ${ }^{1, *}$, Rui Zhao ${ }^{1}$, Yongjun Sun ${ }^{2}$, Qiang Sun ${ }^{1}$, Shixin Zhang ${ }^{1}$ and \\ Yongzhi Liu ${ }^{3}$ \\ 1 Key laboratory of the Three Gorges Reservoir Region's Eco-Environment, State Ministry of Education, \\ Chongqing University, Chongqing 400045, China; 20126128@cqu.edu.cn (X.Z.); zr864361353@126.com (R.Z.); \\ sunqiang6666666@sina.com (Q.S.); 20116511@cqu.edu.cn (S.Z.) \\ 2 College of Urban Construction, Nanjing Tech University, Nanjing 211800, China; sunyongjun@njtech.edu.cn \\ 3 National Centre for International Research of Low-carbon and Green Buildings, Chongqing University, \\ Chongqing 400045, China; yongzhi18653028083@126.com \\ * Correspondence: zhl@cqu.edu.cn; Tel.: +86-23-6512-0827; Fax: +86-23-6512-0827
}

Received: 3 July 2018; Accepted: 27 July 2018; Published: 29 July 2018

\begin{abstract}
The removal of methylene blue (MB) from wastewater has attracted global concerns. In this study, polymer-functionalized magnetic nanoparticles for $\mathrm{MB}$ removal, $\mathrm{Fe}_{3} \mathrm{O}_{4} @ \mathrm{SiO}_{2}-\mathrm{MPS}$ g-AA-AMPS (FSMAA), were successfully synthesized by grafting acrylic acid (AA) and 2-acryl amido-2-methyl-1-propanesulfonic acid (AMPS) on the surface of vinyl-modified $\mathrm{Fe}_{3} \mathrm{O}_{4} @ \mathrm{SiO}_{2}$. With various characterization techniques, it was confirmed that the obtained FSMAA had a core-shell structure, a good magnetic property, and plenty of functional groups on its surface. MB adsorption experiments showed that the adsorption capacity of FSMAA was notably enhanced as the grafted monomer concentration and solution $\mathrm{pH}$ were increased. The adsorption kinetic data and isothermal data were well described by the pseudo-second-order kinetic model and the Langmuir model, respectively. The maximum adsorption capacity of FSMAA was $421.9 \mathrm{mg} \mathrm{g}^{-1}$ with grafted monomer concentration at $2.0 \mathrm{~mol} \mathrm{~L}^{-1}$ and solution $\mathrm{pH}$ at 9 , much higher than those of other adsorbents stated in previous literatures. Based on XPS analysis, surface adsorption mechanism between FSMAA and MB was electrostatic interaction, hydrogen bonding, and hydrophobic interaction. Furthermore, FSMAA was effectively regenerated by acid pickling, and the remaining adsorption capacity was more than $60 \%$ after eight adsorption-regeneration cycles. All the results demonstrated the self-made FSMAA was a desirable adsorbent to remove MB from wastewater.
\end{abstract}

Keywords: magnetic nanoparticles; acrylic acid; 2-acrylamido-2-methyl-1-propanesulfonic acid; adsorption; methylene blue

\section{Introduction}

With industry development, the demand of dyes widely used in textiles, artificial fibers, plastics, foodstuffs, and leathers rises year by year [1]. Dyes discharged into waterbodies can reduce the dissolved oxygen content and the light transmittance while increasing the toxicity of water, resulting in the death of aquatic organisms [2]. Moreover, as strongly toxic and carcinogenic pollutants, dyes pose a serious threat to water environmental safety and human health. In water, even minute quantities of some dyes (e.g., less than 1 ppm) are harmful and undesirable [3,4]. Methylene blue (MB) is one of the most commonly used basic dyes in industry that causes serious human health problems, including vomiting, shock, limb paralysis, tissue death, and so on when it is released into drinking water $[5,6]$. MB is difficult to be degraded under natural conditions due to its complex and stable 
aromatic molecular structure. As a result, the removal of such a dye from wastewater has attracted global concerns. According to literatures, multifarious techniques have been used for the treatment of wastewater containing MB, such as adsorption [5], photocatalytic degradation [7], Fenton-like degradation [8], membrane separation [9], electrochemical process [10], etc. Among these techniques, adsorption is thought to be a preferred method because of its low cost, simple design and operation, high efficiency, and insensitivity to poisonous substances [3,11].

$\mathrm{Fe}_{3} \mathrm{O}_{4}$ magnetic nanoparticles (MNPs) are currently regarded as base materials for their advantages, such as high surface area, facile synthesis, and low toxicity [12]. However, due to their poor stability in extremely acid environment (i.e., $\mathrm{pH}<2$ ), the regeneration process (usually under acid environment) is limited, in other words, the application of $\mathrm{Fe}_{3} \mathrm{O}_{4}$ MNPs as adsorbents is limited. Furthermore, the surface of $\mathrm{Fe}_{3} \mathrm{O}_{4}$ MNPs, including surface charge, tendency of aggregation, and so on, is a limitation for their application. A frequently-used method to overcome this disadvantage is to cover $\mathrm{Fe}_{3} \mathrm{O}_{4} \mathrm{MNPs}$ by an outer silica shell that acts as a protective layer and separates the magnetic core from the external environment to achieve a better stability [13]. However, the adsorption performance of $\mathrm{Fe}_{3} \mathrm{O}_{4} @ \mathrm{SiO}_{2} \mathrm{MNPs}$ is usually insufficient because of few functional groups on its surface. As a result, organic polymers with plenty of functional groups are generally adopted to functionalize $\mathrm{Fe}_{3} \mathrm{O}_{4} @ \mathrm{SiO}_{2}$ MNPs. For example, Yure Ge et al. [13] used acrylamide, methylacryloxyethyltrimethyl ammonium chloride, and 2-acrylamido-2-methyl-1-propanesulfonic acid to functionalize $\mathrm{Fe}_{3} \mathrm{O}_{4} @ \mathrm{SiO}_{2} \mathrm{MNPs}$. The multifunctionalized MNPs were proven to be effective for oilfield wastewater purification. Farzad Javaheri and Shadi Hassanajili [14] studied the removal of nitrate ions from aqueous solutions by poly(4-vinylpyridine)-functionalized MNPs. Kun Li et al. [15] adopted chitosan and polyacrylamide to functionalize $\mathrm{Fe}_{3} \mathrm{O}_{4} @ \mathrm{SiO}_{2} \mathrm{MNPs}$. The obtained composite had a highly selective adsorption of mercury ions from water.

In this study, polymer-functionalized MNPs with core-shell structure named $\mathrm{Fe}_{3} \mathrm{O}_{4} @ \mathrm{SiO}_{2}-$ MPS-g-AA-AMPS (FSMAA) were synthesized as a novel adsorbent for the removal of MB from aqueous solutions. Various characterization techniques were used to characterize the structure, physic-chemical properties, and magnetic feature of FSMAA. The effects of grafted monomer concentration and solution $\mathrm{pH}$ on the adsorption performance were investigated. Adsorption kinetics, isotherms, and mechanism were also studied. The stability and regeneration ability of FSMAA were discussed to demonstrate its application prospect.

\section{Materials and Methods}

\subsection{Materials}

Triiron tetraoxide $\left(\mathrm{Fe}_{3} \mathrm{O}_{4}, 50 \mathrm{~nm}\right)$ was obtained from Micxy Chemical Co., Ltd. (Chengdu, China). Ammonia solution (25-28\% $\mathrm{NH}_{3}$ in $\mathrm{H}_{2} \mathrm{O}$ ), anhydrous ethanol (99.7\% purity), hydrochloric acid ( $\mathrm{HCl}$ ), and sodium hydroxide $(\mathrm{NaOH})$ were purchased from Chongqing Chuandong Chemical Co., Ltd. (Chongqing, China). Ammonium persulfate, methylene blue (MB), tetraethyl orthosilicate (TEOS), and acrylic acid (AA, 99.5\% purity) were obtained from Chengdu Kelong Chemical Reagent Co., Ltd. (Chengdu, China). 2-acrylamido-2-methyl-1-propanesulfonic acid (AMPS, 98\% purity) and 3-(trimethoxysilyl)propyl methacrylate (MPS, 97\% purity) were purchased from Aladdin Reagent Co., Ltd. (Shanghai, China). All reagents were used without further treatment and Milli-Q ultrapure water $\left(18 \mathrm{M} \Omega \mathrm{cm}^{-1}\right)$ was used for preparing aqueous solutions.

\subsection{Synthesis of Magnetic Adsorbent}

\subsubsection{Synthesis of $\mathrm{Fe}_{3} \mathrm{O}_{4} @ \mathrm{SiO}_{2} \mathrm{MNPs}$}

$\mathrm{Fe}_{3} \mathrm{O}_{4} @ \mathrm{SiO}_{2}$ MNPs were synthesized by Stöber method according to the previous researches [13,16]. $\mathrm{Fe}_{3} \mathrm{O}_{4}(1.2 \mathrm{~g})$ was homogeneously dispersed in the mixture of anhydrous ethanol $(400 \mathrm{~mL})$, ultrapure water $(200 \mathrm{~mL})$, and ammonia solution $(6 \mathrm{~mL})$. Then $18 \mathrm{~mL}$ TEOS was slowly 
added and the resulting dispersion was mechanically stirred for $8 \mathrm{~h}$ in a water bath $\left(25^{\circ} \mathrm{C}\right)$. Finally, the obtained $\mathrm{Fe}_{3} \mathrm{O}_{4} @ \mathrm{SiO}_{2} \mathrm{MNPs}$ were separated by a magnet, washed repeatedly with anhydrous ethanol and ultrapure water, and dried in a vacuum oven at $60^{\circ} \mathrm{C}$.

\subsubsection{Synthesis of $\mathrm{Fe}_{3} \mathrm{O}_{4} @ \mathrm{SiO}_{2}-\mathrm{MPS} \mathrm{MNPs}$}

The surface-modified $\mathrm{Fe}_{3} \mathrm{O}_{4} @ \mathrm{SiO}_{2} \mathrm{MNPs}$ were synthesized according to a reported literature with the method being slightly changed [13]. $\mathrm{Fe}_{3} \mathrm{O}_{4} @ \mathrm{SiO}_{2} \mathrm{MNPs}$ were dispersed in a three-necked flask containing $200 \mathrm{~mL}$ anhydrous ethanol. A mixture of MPS (9 mL) and anhydrous ethanol (100 mL) was added dropwise into the flask after the dispersion was completely deoxygenated by bubbling with pure $\mathrm{N}_{2}(99.99 \%)$. Then the flask was immediately sealed and mechanically stirred for $12 \mathrm{~h}$ in a water bath $\left(78^{\circ} \mathrm{C}\right)$. Lastly, the vinyl-modified $\mathrm{Fe}_{3} \mathrm{O}_{4} @ \mathrm{SiO}_{2} \mathrm{MNPs}\left(\mathrm{Fe}_{3} \mathrm{O}_{4} @ \mathrm{SiO}_{2}-\mathrm{MPS}\right)$ were collected by magnetic separation, washed repeatedly with anhydrous ethanol and ultrapure water, and dried subsequently in a vacuum oven at $60^{\circ} \mathrm{C}$.

\subsubsection{Synthesis of FSMAA MNPs}

FSMAA MNPs were synthesized by one-pot free radical polymerization. $\mathrm{Fe}_{3} \mathrm{O}_{4} @ \mathrm{SiO}_{2}-\mathrm{MPS} \mathrm{MNPs}$ $(0.35 \mathrm{~g})$ were dispersed in a three-necked flask containing $100 \mathrm{~mL}$ ultrapure water and sonicated for $5 \mathrm{~min}$ to form a homogeneous dispersion. Then, a predetermined amount of solution containing grafted monomers, AA and AMPS (i.e., the mole ratio of AA and AMPS = 3:1; the grafted monomer concentration $=0.2,0.9,1.2,1.5,2.0,2.5 \mathrm{~mol} \mathrm{~L}^{-1}$ ), was added into the dispersion. The flask was bubbled with pure $\mathrm{N}_{2}(99.99 \%)$ for $20 \mathrm{~min}$ to remove oxygen absolutely. After a certain mass of initiator ammonium persulfate (i.e., the initiator concentration $=0.9 \%$ ) being added, the flask was immediately sealed and mechanically stirred for $7 \mathrm{~h}$ in a water bath $\left(65^{\circ} \mathrm{C}\right)$. Finally, the obtained magnetic adsorbent was harvested via magnetic separation, washed repeatedly with anhydrous ethanol and ultrapure water, and dried subsequently in a vacuum oven at $60^{\circ} \mathrm{C}$.

\subsection{Characterization}

The morphology analysis was carried out by transmission electron microscope (TEM, HT7700, Hitachi, Tokyo, Japan). Fourier transform infrared (FTIR) spectra were made by a spotlight 200 FTIR spectrometer (Nicolet iS5, Nicolet, Madison, WI, USA) in the wavenumber range from 4000 to $500 \mathrm{~cm}^{-1}$. X-ray diffraction (XRD) patterns were obtained by an X-ray diffractometer (DMAX/2C, Rigaku, Tokyo, Japan) with the graphite monochromatized $\mathrm{Cu}-\mathrm{K} \alpha$ radiation $(\lambda=1.54056 \AA)$. $\mathrm{X}$-ray photoelectron spectroscopy (XPS) spectra were recorded by an XPS spectrometer (ESCALAB250Xi, Thermo Fisher Scientific, Waltham, MA, USA) with Al-K $\alpha$ X-ray used as the excitation source. Magnetic hysteresis loops were determined by a vibrating sample magnetometer (VSM, VSM 7410, LakeShore, Carson, CA, USA) at room temperature. Zeta potentials were measured by a Zetasizer Nano ZS90 (Malvern Instruments Ltd., Malvern, UK). The leaching concentration of Fe in water was tested with an inductively coupled plasma-optical emission spectroscope (ICP-OES, Optima 2100DV, Perkin-Elmer Instruments, Waltham, MA, USA).

\subsection{Adsorption Experiments}

The adsorption ability of FSMAA was investigated by batch adsorption experiments with MB used as the target adsorbate. All the experiments were conducted in $50 \mathrm{~mL}$ conical flasks containing certain volumes of MB solutions and $1.0 \mathrm{~g} \mathrm{~L}^{-1}$ FSMAA. These flasks were shaken at $303 \mathrm{~K}$ in a constant temperature shaking bath with a shaking speed of $200 \mathrm{rpm}$. After a predetermined time, sample solutions were taken out by a transfer liquid gun under the help of an external magnet to avoid FSMAA being simultaneously taken out. The concentrations of MB in sample solutions were calculated via the calibration curve (shown in Figure 1) between MB concentration and absorbance measured by a UV-visible spectrophotometer (TU-1901, Beijing Purkinje General Instrument Co., Ltd., Beijing, China) 
at the maximum adsorption wavelength of $665 \mathrm{~nm}$ (referring to the insert of Figure 1). Each adsorption experiment was repeated three times and the final results were averaged.

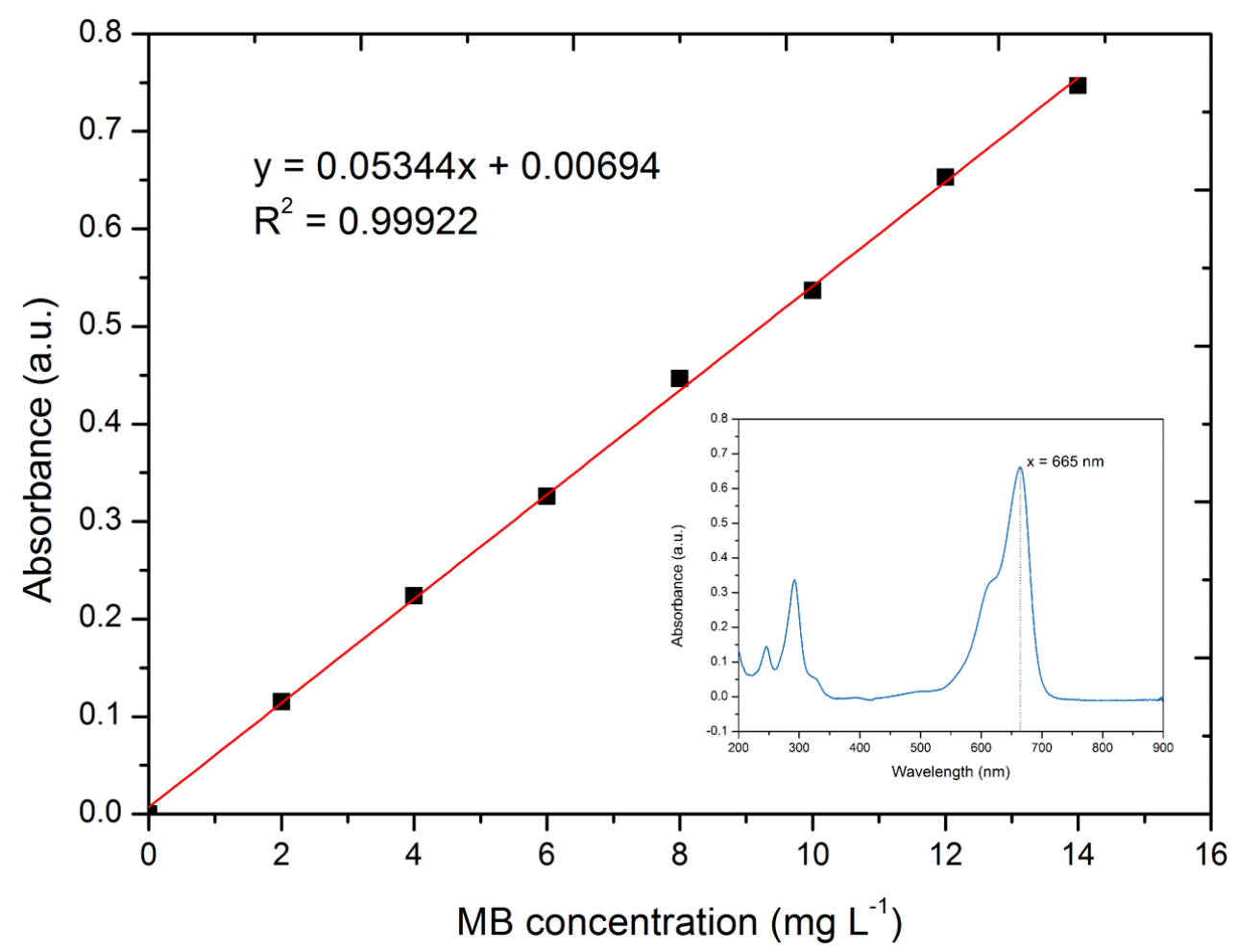

Figure 1. Calibration curve between MB concentration and absorbance (the insert is the UV-vis spectrum of MB in solution).

\subsubsection{Effects of Grafted Monomer Concentration and Solution $\mathrm{pH}$}

The effects of grafted monomer concentration and solution $\mathrm{pH}$ on the adsorption performance were investigated with monomer concentrations from 0.2 to $2.5 \mathrm{~mol} \mathrm{~L}^{-1}$ and $\mathrm{pH}$ from 2.0 to 10.0 , respectively. The solution $\mathrm{pH}$ was adjusted with $1 \mathrm{~mol} \mathrm{~L}^{-1} \mathrm{NaOH}$ and/or $1 \mathrm{~mol} \mathrm{~L}^{-1} \mathrm{HCl}$ solution. The initial concentration and the volume of $\mathrm{MB}$ solution were $500 \mathrm{mg} \mathrm{L}^{-1}$ and $10 \mathrm{~mL}$, respectively, and the shaking time was $4 \mathrm{~h}$. The equilibrium adsorption amount of $\mathrm{MB}\left(\mathrm{q}_{\mathrm{e}}, \mathrm{mg} \mathrm{g}^{-1}\right)$ was calculated by Equation (1).

$$
\mathrm{q}_{\mathrm{e}}=\frac{\mathrm{V} \times\left(\mathrm{C}_{\mathrm{i}}-\mathrm{C}_{\mathrm{e}}\right)}{\mathrm{m}}
$$

where $C_{i}\left(\mathrm{mg} \mathrm{L}^{-1}\right)$ and $\mathrm{C}_{\mathrm{e}}\left(\mathrm{mg} \mathrm{L}^{-1}\right)$ are the initial and the equilibrium concentrations of $\mathrm{MB}$, respectively, $\mathrm{V}(\mathrm{L})$ is the volume of the MB solution, and $\mathrm{m}(\mathrm{g})$ is the mass of FSMAA.

\subsubsection{Adsorption Kinetics}

In adsorption kinetic experiments, the initial concentration, volume, and $\mathrm{pH}$ of $\mathrm{MB}$ solution were $500 \mathrm{mg} \mathrm{L}^{-1}, 100 \mathrm{~mL}$, and 9, respectively. At predetermined time intervals, $0.5 \mathrm{~mL}$ sample solutions were taken out by magnetic separation to analyze $\mathrm{MB}$ concentrations remaining in the solution. The pseudo-first-order, pseudo-second-order, and intraparticle diffusion kinetic models were adopted to analyze the adsorption data, as shown in Equations (2)-(4), respectively.

$$
\begin{gathered}
\ln \left(\mathrm{q}_{\mathrm{e}}-\mathrm{q}_{\mathrm{t}}\right)=\ln \mathrm{q}_{\mathrm{e}}-\mathrm{k}_{1} \mathrm{t} \\
\frac{\mathrm{t}}{\mathrm{q}_{\mathrm{t}}}=\frac{1}{\mathrm{k}_{2} \mathrm{q}_{\mathrm{e}}^{2}}+\frac{\mathrm{t}}{\mathrm{q}_{\mathrm{e}}}
\end{gathered}
$$




$$
\begin{aligned}
& \mathrm{q}_{\mathrm{t}}=\mathrm{k}_{\mathrm{i}} \times \mathrm{t}^{1 / 2}+\mathrm{C} \\
& \mathrm{q}_{\mathrm{t}}=\frac{\mathrm{V} \times\left(\mathrm{C}_{\mathrm{i}}-\mathrm{C}_{\mathrm{t}}\right)}{\mathrm{m}}
\end{aligned}
$$

where $\mathrm{q}_{\mathrm{t}}\left(\mathrm{mg} \mathrm{g}^{-1}\right)$ is the adsorption amount of MB at time $\mathrm{t}(\mathrm{min}), \mathrm{k}_{1}\left(\mathrm{~min}^{-1}\right), \mathrm{k}_{2}\left(\mathrm{~g} \mathrm{mg}^{-1} \min ^{-1}\right)$, and $\mathrm{k}_{\mathrm{i}}\left(\mathrm{mg} \mathrm{g}^{-1} \mathrm{~min}^{-1 / 2}\right)$ are the rate constants of pseudo-first-order model, pseudo-second-order model, and intraparticle diffusion model, respectively, and $\mathrm{C}$ is the parameter.

\subsubsection{Adsorption Isotherms}

In adsorption isothermal experiments, the shaking time, volume, and $\mathrm{pH}$ of $\mathrm{MB}$ solution were $4 \mathrm{~h}, 10 \mathrm{~mL}$, and 9, respectively. The initial concentration of MB solution was set from $50 \mathrm{mg}$ $\mathrm{L}^{-1}$ to $1000 \mathrm{mg} \mathrm{L}^{-1}$. Three isothermal adsorption models, including Langmuir, Freundlich, and Dubinin-Radushkevich (D-R), shown in Equations (6)-(8), respectively, were used to analyze the adsorption data.

$$
\begin{gathered}
\frac{\mathrm{C}_{\mathrm{e}}}{\mathrm{q}_{\mathrm{e}}}=\frac{\mathrm{C}_{\mathrm{e}}}{\mathrm{q}_{\mathrm{m}}}+\frac{1}{\mathrm{q}_{\mathrm{m}} \times \mathrm{K}_{\mathrm{L}}} \\
\ln \mathrm{q}_{\mathrm{e}}=\ln \mathrm{K}_{\mathrm{F}}+\frac{1}{\mathrm{n}} \ln \mathrm{C}_{\mathrm{e}} \\
\ln \mathrm{q}_{\mathrm{e}}=\ln \mathrm{q}_{\mathrm{D}}-\mathrm{K}_{\mathrm{D}} \times\left[\mathrm{RT} \times \ln \left(1+\frac{1}{\mathrm{C}_{\mathrm{e}}}\right)\right]^{2}
\end{gathered}
$$

where $\mathrm{q}_{\mathrm{m}}\left(\mathrm{mg} \mathrm{g}^{-1}\right)$ and $\mathrm{q}_{\mathrm{D}}\left(\mathrm{mg} \mathrm{g}^{-1}\right)$ are the maximum adsorption amounts of $\mathrm{MB}$ in the Langmuir model and in the D-R model, respectively; $\mathrm{K}_{\mathrm{L}}\left(\mathrm{L} \mathrm{mg}{ }^{-1}\right), \mathrm{K}_{\mathrm{F}}$, and $\mathrm{K}_{\mathrm{D}}\left(\mathrm{mol}^{2} \mathrm{~kJ}^{-2}\right)$ are the model constants of the Langmuir model, Freundlich model, and D-R model, respectively; $\mathrm{n}$ is the other model constant of the Freundlich model; $\mathrm{R}\left(\mathrm{J} \mathrm{mol}^{-1} \mathrm{~K}^{-1}\right)$ is the gas constant; and $\mathrm{T}(\mathrm{K})$ is the thermodynamic temperature.

\subsection{Stability and Regeneration Experiments}

In stability experiments, 10 mg FSMAA was dispersed separately in 11 conical flasks, each containing $10 \mathrm{~mL}$ water with $\mathrm{pH}$ values ranged from 0 to 10 . The leaching concentrations of $\mathrm{Fe}$ in water were tested with ICP-OES after these flasks were shaken for $12 \mathrm{~h}$ at $303 \mathrm{~K}$ in a constant temperature shaking bath. In regeneration experiments, $1 \mathrm{~mol} \mathrm{~L}^{-1}, 0.1 \mathrm{~mol} \mathrm{~L}^{-1}$, and $0.01 \mathrm{~mol} \mathrm{~L}^{-1} \mathrm{HCl}$ were selected as the desorbents. Firstly, $80 \mathrm{mg}$ FSMAA was added into $80 \mathrm{~mL}$ MB solution, and after the adsorption was completed, the MB-loaded adsorbent (FSMAA-MB) was taken out by magnetic separation. Secondly, FSMAA-MB was dispersed in $80 \mathrm{~mL}$ desorbent. The regeneration reaction was carried out for $12 \mathrm{~h}$ at $303 \mathrm{~K}$ in a constant temperature shaking bath. Lastly, the regenerative FSMAA was used for the next adsorption-regeneration cycle. The adsorption-regeneration experiments were repeated for eight cycles in total.

\section{Results and Discussion}

\subsection{Synthesis and Characterization}

The magnetic adsorbent FSMAA with a core-shell structure was synthesized by three steps: (1) covering the $\mathrm{Fe}_{3} \mathrm{O}_{4}$ magnetic core with a silica shell by Stöber method; (2) modifying the silica shell with silane coupling agent MPS; and (3) obtaining the polymer-functionalized MNPs by grafting AA and AMPS on the surface of $\mathrm{Fe}_{3} \mathrm{O}_{4} @ \mathrm{SiO}_{2}$-MPS. The grafting reaction followed the general reaction rules of free radical polymerization and it could be divided into several stages, including chain initiation, chain growth, chain termination, and a certain degree of chain transfer. The grafting route is depicted in Scheme 1 and the whole synthesis process is illustrated in Figure 2. 


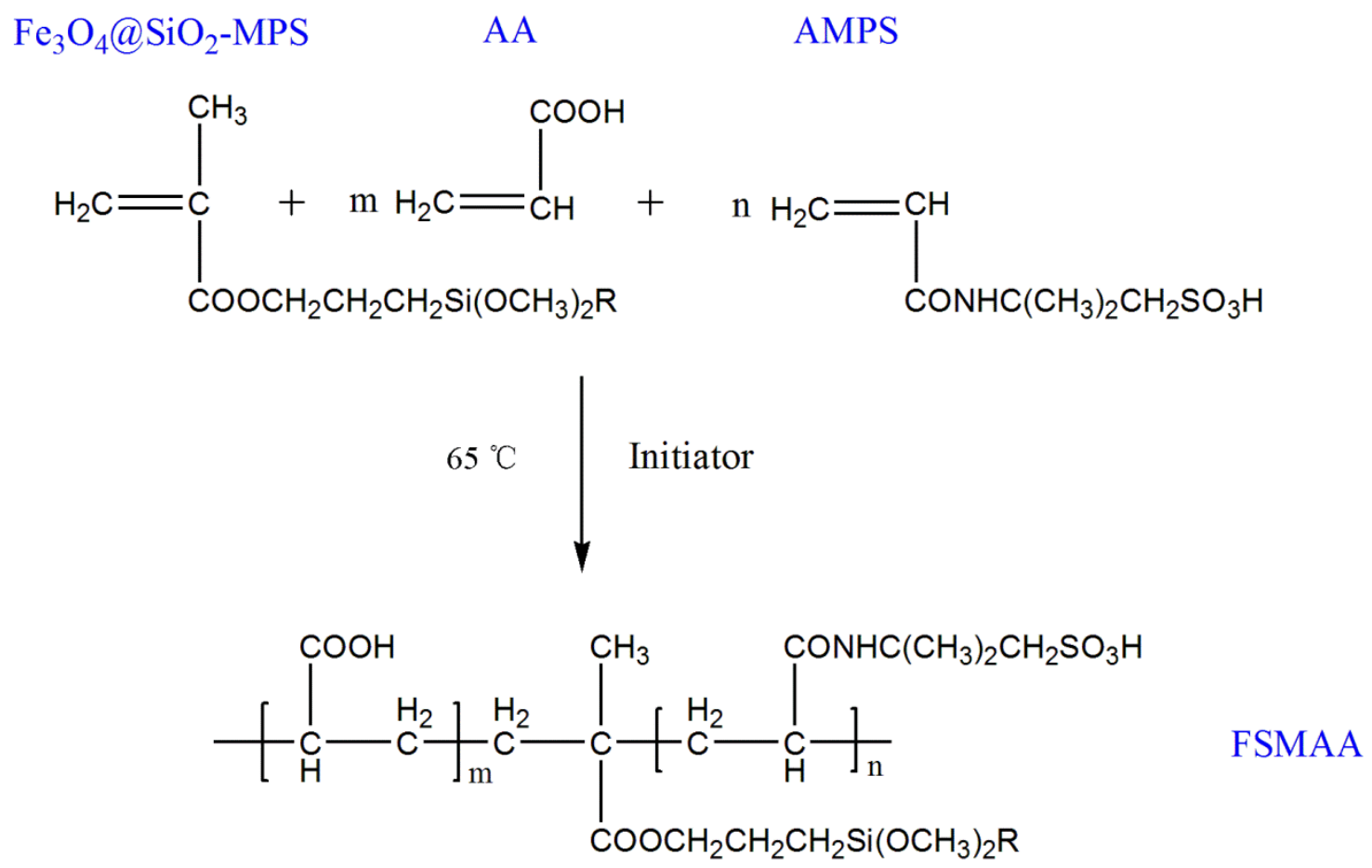

or

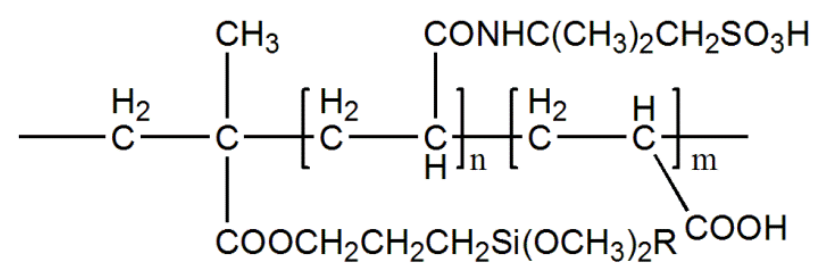

or

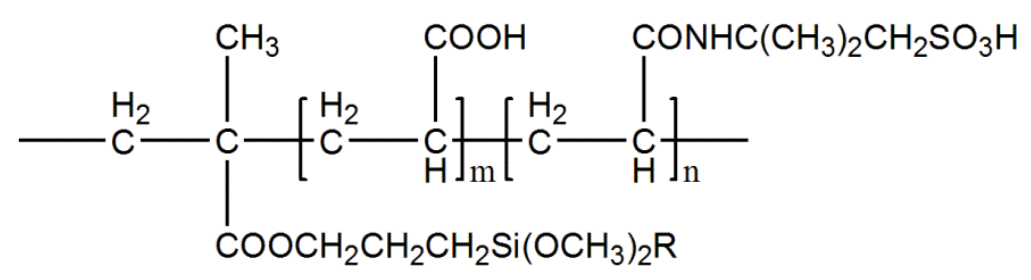

FSMAA

Scheme 1. Scheme of grafting polymerization ( $\mathrm{R}$ represents $\mathrm{Fe}_{3} \mathrm{O}_{4} @ \mathrm{SiO}_{2}$ ). 


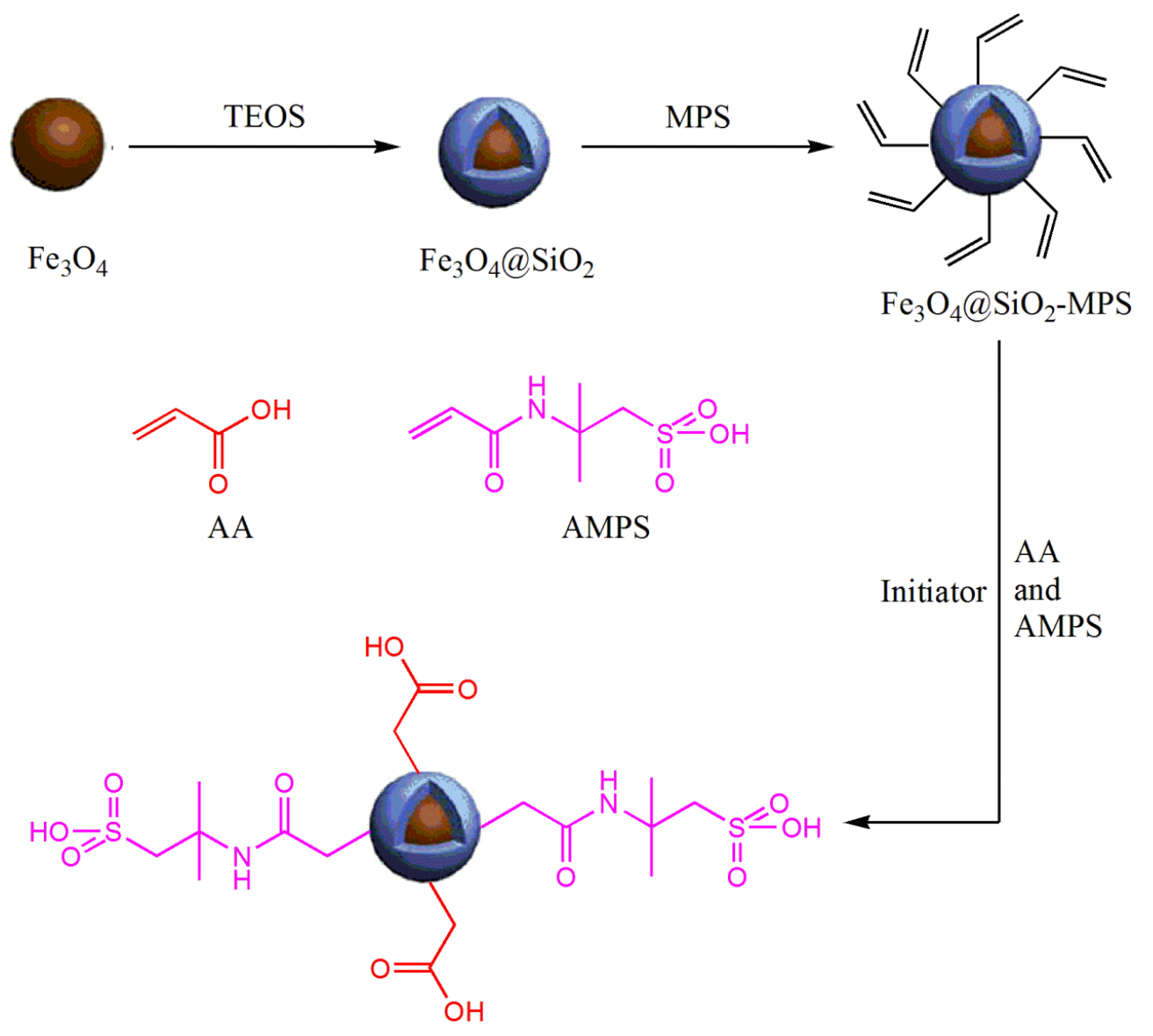

$$
\mathrm{Fe}_{3} \mathrm{O}_{4} @ \mathrm{SiO}_{2} \text {-MPS-g-AA-AMPS (FSMAA) }
$$

Figure 2. Schematic diagram on synthesis of FSMAA.

The core-shell structure of FSMAA was demonstrated by TEM, as seen in Figure 3. For FSMAA and $\mathrm{Fe}_{3} \mathrm{O}_{4} @ \mathrm{SiO}_{2}$, there were bright layers of shell with main thicknesses of $14.3 \mathrm{~nm}$ and $10.5 \mathrm{~nm}$, respectively, while for $\mathrm{Fe}_{3} \mathrm{O}_{4}$, no layer was observed. This phenomenon indicated the successful synthesis of polymer and $\mathrm{SiO}_{2} . \mathrm{Fe}_{3} \mathrm{O}_{4}, \mathrm{Fe}_{3} \mathrm{O}_{4} @ \mathrm{SiO}_{2}$, and FSMAA were almost spherical and had a certain degree of adhering owing to their nanometer size and high reactivity [17].
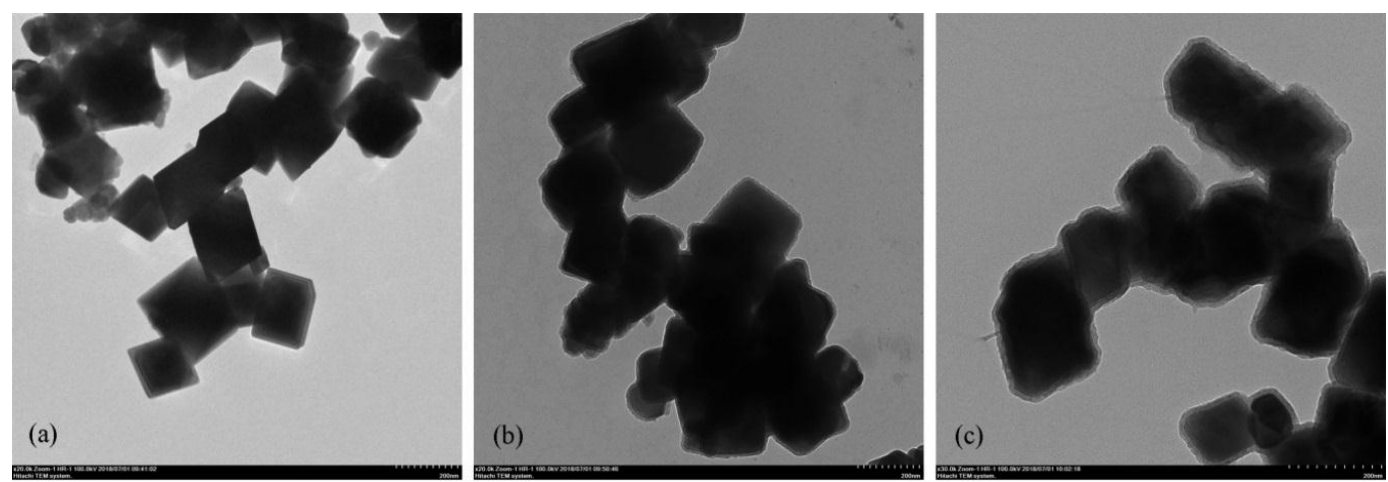

Figure 3. TEM images of (a) $\mathrm{Fe}_{3} \mathrm{O}_{4},(\mathbf{b}) \mathrm{Fe}_{3} \mathrm{O}_{4} @ \mathrm{SiO}_{2}$, and (c) FSMAA (the scale bars were $200 \mathrm{~nm}$ for a, b, and $\mathbf{c}$ ). 
Figure 4a shows the FTIR spectra of $\mathrm{Fe}_{3} \mathrm{O}_{4}, \mathrm{Fe}_{3} \mathrm{O}_{4} @ \mathrm{SiO}_{2}$, and FSMAA. The adsorption peaks at $574 \mathrm{~cm}^{-1}, 1633 \mathrm{~cm}^{-1}$, and $3447 \mathrm{~cm}^{-1}$ appeared in all samples' spectra and were attributed to

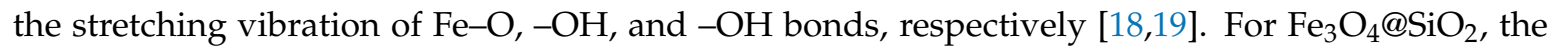
adsorption peaks at $794 \mathrm{~cm}^{-1}$ and $1082 \mathrm{~cm}^{-1}$ corresponded to the amorphous silica $\mathrm{Si}-\mathrm{O}-\mathrm{Si}$ vibration, and the peak at $958 \mathrm{~cm}^{-1}$ was associated with the $\mathrm{Si}-\mathrm{OH}$ vibration $[20,21]$. The successful synthesis of $\mathrm{SiO}_{2}$ shell was demonstrated by these above peaks. For FSMAA, the adsorption peaks at $1211 \mathrm{~cm}^{-1}$ and $1088 \mathrm{~cm}^{-1}$ were the asymmetric and symmetric bands of $\mathrm{SO}_{2}$ in $-\mathrm{SO}_{3} \mathrm{H}$, respectively [13], and the adsorption peak at $1720 \mathrm{~cm}^{-1}$ was assigned to $-\mathrm{COOH}$ bond [22]. Notably, the Si-O-Si bond at $1082 \mathrm{~cm}^{-1}$ was covered by the symmetric band of $\mathrm{SO}_{2}$ in $-\mathrm{SO}_{3} \mathrm{H}$ at $1088 \mathrm{~cm}^{-1}$. The appearance of $-\mathrm{COOH}$ and $-\mathrm{SO}_{3} \mathrm{H}$ in FSMAA indicated that the organic polymer was successfully grafted on the surface of $\mathrm{Fe}_{3} \mathrm{O}_{4} @ \mathrm{SiO}_{2}$-MPS.

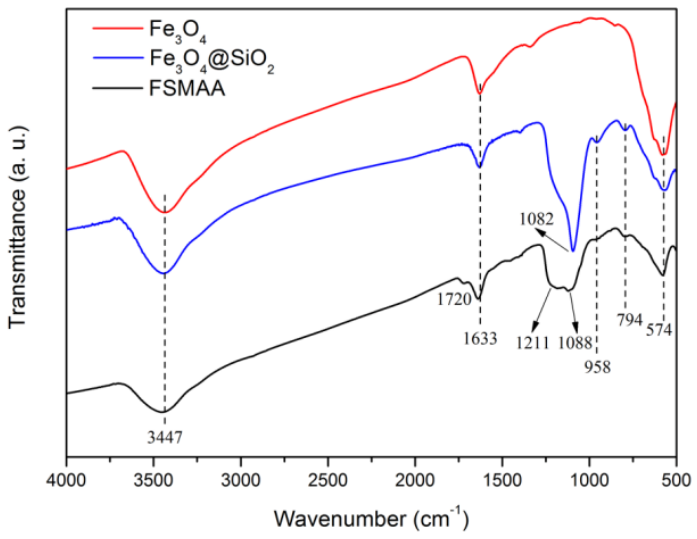

(a)

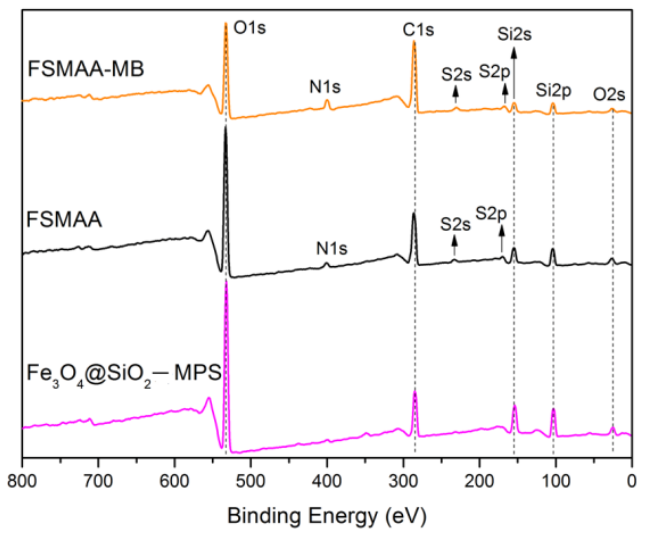

(c)

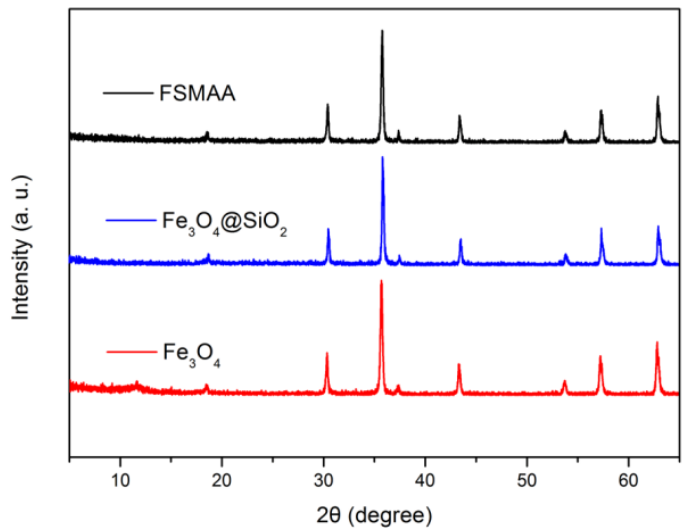

(b)

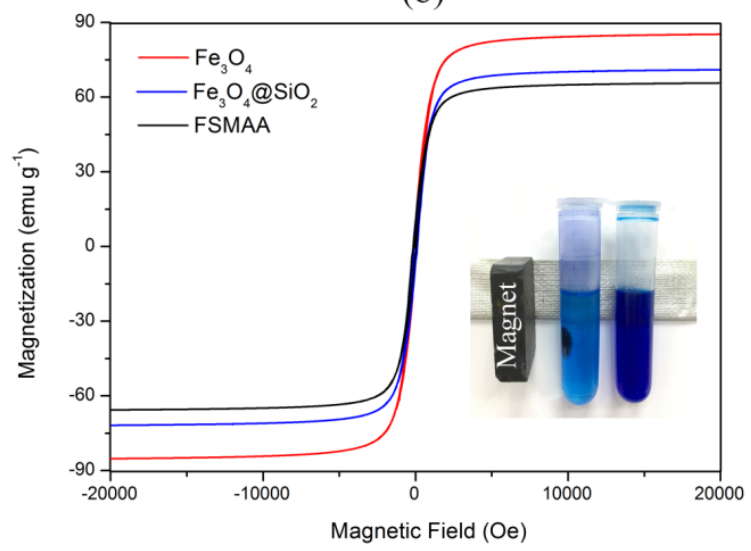

(d)

Figure 4. Characterization results of (a) FTIR spectra; (b) XRD patterns; (c) XPS full scanned spectra; (d) magnetic hysteresis loops (the insert is the image of MB solutions before and after adsorption; the adsorbent dosage, initial concentration, and $\mathrm{pH}$ are $1.0 \mathrm{~g} \mathrm{~L}^{-1}, 200 \mathrm{mg} \mathrm{L}^{-1}$, and 9.0, respectively).

The XRD patterns were studied to investigate the crystal structures of $\mathrm{Fe}_{3} \mathrm{O}_{4}, \mathrm{Fe}_{3} \mathrm{O}_{4} @ \mathrm{SiO}_{2}$, and FSMAA, as shown in Figure $4 \mathrm{~b}$. The fact that the characteristic peaks located at $30.4^{\circ}, 35.7^{\circ}, 43.3^{\circ}$, $53.7^{\circ}, 57.2^{\circ}$, and $62.8^{\circ}$ respectively assigned to (220), (311), (400), (422), (511), and (440) planes of $\mathrm{Fe}_{3} \mathrm{O}_{4}$ (JCPDS card No. 19-0629) were maintained in $\mathrm{Fe}_{3} \mathrm{O}_{4} @ \mathrm{SiO}_{2}$ and FSMAA indicated that the coating process did not change the crystal phases of $\mathrm{Fe}_{3} \mathrm{O}_{4}$ [23].

The qualitative analysis of chemical elements was conducted by XPS fully scanned spectra, as shown in Figure 4c. The existence of $\mathrm{Si}$ in all samples indicated a successful synthesis of $\mathrm{SiO}_{2}$. New elements, including $\mathrm{N}$ and $\mathrm{S}$, showing up in FSMAA and FSMAA-MB illustrated the successful grafting of AMPS. Since no peak corresponding to Fe was observed in all samples' spectra, the coating 
of $\mathrm{SiO}_{2}$ was confirmed. And as there were lower intensity peaks corresponding to $\mathrm{Si}$ in the spectra of FSMAA and FSMAA-MB, the existence of AA and AMPS could be inferred.

Figure $4 \mathrm{~d}$ shows the magnetic hysteresis loops of $\mathrm{Fe}_{3} \mathrm{O}_{4}, \mathrm{Fe}_{3} \mathrm{O}_{4} @ \mathrm{SiO}_{2}$, and FSMAA. The obtained saturation magnetization values at room temperature were 84.94, 71.33, and $65.31 \mathrm{emu} \mathrm{g}^{-1}$ for $\mathrm{Fe}_{3} \mathrm{O}_{4}$, $\mathrm{Fe}_{3} \mathrm{O}_{4} @ \mathrm{SiO}_{2}$, and FSMAA, respectively. Although the increase of nonmagnetic substances, including $\mathrm{SiO}_{2}$, AA, and AMPS, caused the decrease of saturation magnetization, the final product FSMAA still remained a high saturation magnetization that could significantly accelerate separation, as shown in the insert of Figure $4 \mathrm{~d}$.

\subsection{Adsorption of $M B$}

\subsubsection{Effect of Grafted Monomer Concentration on Adsorption}

As illustrated in Figure 5a, the saturation magnetization of synthetic products decreased from $70.90 \mathrm{emu} \mathrm{g}^{-1}$ to $65.31 \mathrm{emu} \mathrm{g}^{-1}$ with the increase of grafted monomer concentration from $0.0 \mathrm{~mol} \mathrm{~L}^{-1}$ to $2.0 \mathrm{~mol} \mathrm{~L}^{-1}$, demonstrating more polymers were grafted onto MNPs. Figure $5 \mathrm{~b}$ shows that the grafting of AA and AMPS on the surface of $\mathrm{Fe}_{3} \mathrm{O}_{4} @ \mathrm{SiO}_{2}-\mathrm{MPS}$ has a good effect on MB adsorption. Since there were more and more polymers with abundant functional groups being introduced on the surface of $\mathrm{Fe}_{3} \mathrm{O}_{4} @ \mathrm{SiO}_{2}$-MPS with the increase of grafted monomer concentration from $0.0 \mathrm{~mol} \mathrm{~L}^{-1}$ to $2.0 \mathrm{~mol} \mathrm{~L}^{-1}$, the equilibrium adsorption amount significantly increased from $40.2 \mathrm{mg} \mathrm{g}^{-1}$ to $346.2 \mathrm{mg} \mathrm{g}^{-1}$. However, as the monomer concentration further increased to $2.5 \mathrm{~mol} \mathrm{~L}^{-1}$, there was only a little increase in equilibrium adsorption amount. This phenomenon was due to the possibility that the grafted monomer concentration could largely affect polymerization. A higher monomer concentration contributed to generating more monomer free radicals and to accelerating the polymerization. However, a too high polymerization speed would lead to chain transfer or chain termination, and stop the polymerization [24]. Therefore, the optimized monomer concentration was determined to be $2.0 \mathrm{~mol} \mathrm{~L}^{-1}$. In the following adsorption experiments, FSMAA MNPs with grafted monomer concentrations of $0.9 \mathrm{~mol} \mathrm{~L}^{-1}, 1.5 \mathrm{~mol} \mathrm{~L}^{-1}$, and $2.0 \mathrm{~mol} \mathrm{~L}^{-1}$ (recorded as FSMAA 0.9 , FSMAA 1.5, and FSMAA 2.0, respectively) were used as the adsorbents.
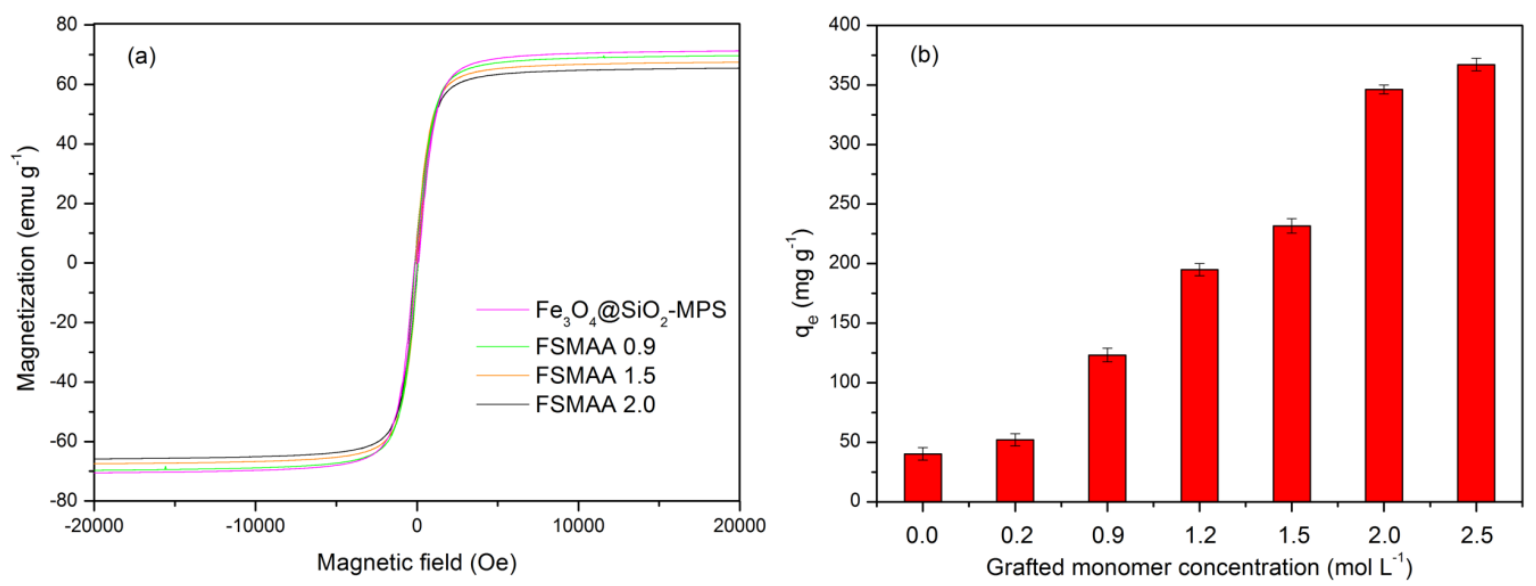

Figure 5. Effect of grafted monomer concentration on (a) magnetization and (b) adsorption (solution $\mathrm{pH}=9.0)$.

\subsubsection{Effect of Solution $\mathrm{pH}$ on Adsorption}

The solution $\mathrm{pH}$ strongly affected not only the zeta potentials on the surface of the adsorbent, but also the existence forms of the adsorbate. Since basic dyes were unstable under high pH (generally $>10$ ) environment, the solution $\mathrm{pH}$ value between 2 and 10 was selected to investigate its effect on $\mathrm{MB}$ adsorption [25]. Because of the deprotonation of $-\mathrm{SO}_{3} \mathrm{H}$ and $-\mathrm{COOH}$, the zeta potentials on the surface 
of FSMAA declined with the increase of $\mathrm{pH}$, as shown in Figure 6a. Among these three adsorbents, the zeta potentials of FSMAA 2.0 were the minimum in the tested $\mathrm{pH}$ range owing to the fact that more $-\mathrm{SO}_{3} \mathrm{H}$ and $-\mathrm{COOH}$ were introduced to its surface. Corresponding to the results obtained in zeta potentials experiments, the equilibrium adsorption amount of FSMAA significantly increased with the increase of $\mathrm{pH}$ and it reached the maximum when FSMAA 2.0 was used, as shown in Figure 6b. A lower $\mathrm{pH}$ environment weakened the electrostatic interaction between adsorbents and dyes, and it had abundant protons to compete for adsorption sites with dyes, leading to an unsatisfactory adsorption performance $[26,27]$. These phenomena suggested that electrostatic interaction was the main mechanism of FSMAA to remove MB from wastewater.
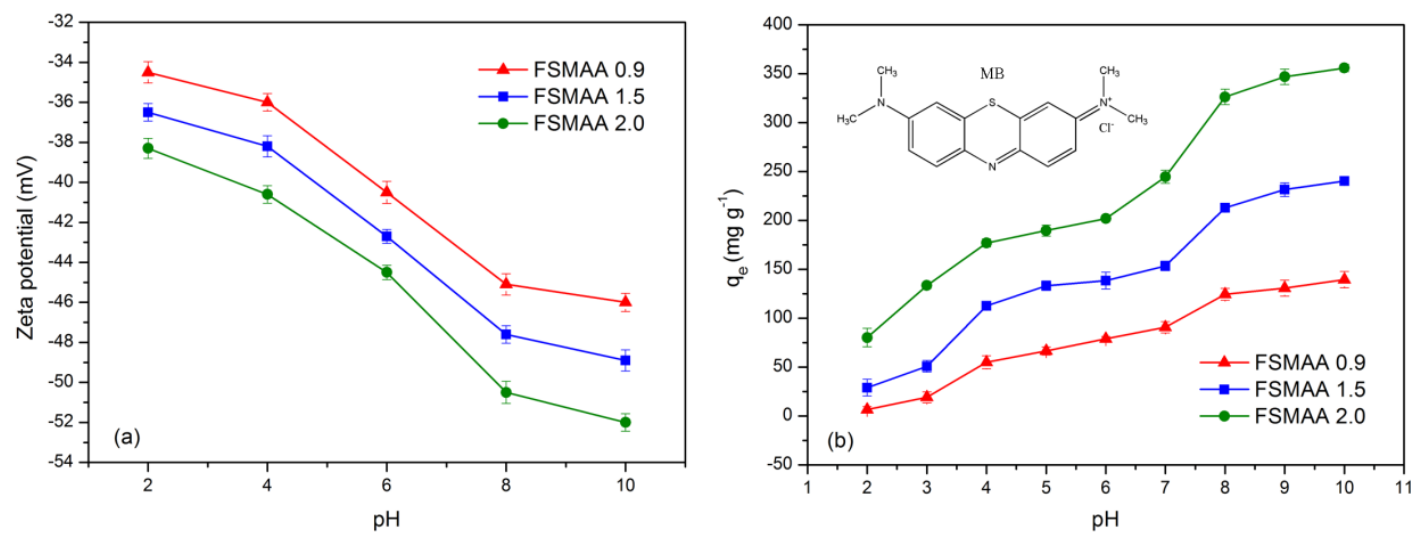

Figure 6. (a) Zeta potentials/pH profiles of FSMAA 0.9, FSMAA 1.5, and FSMAA 2.0 (electrolyte concentration $\left.=0.7 \mathrm{~g} \mathrm{~L}^{-1}\right)$; (b) effect of solution $\mathrm{pH}$ on adsorption (the insert is the image of MB's chemical structure).

\subsubsection{Adsorption Kinetics}

In order to understand the adsorption mechanism and speed control step, adsorption kinetics was studied by using FSMAA 0.9, FSMAA 1.5, and FSMAA 2.0. Since abundant active sites on the surface of FSMAA available for adsorption were gradually occupied by MB with the increase of time, the adsorption of MB was very fast in the initial stage, then increased slightly and finally reached a plateau, as illustrated in Figure 7a; this phenomenon was also observed in other adsorption experiments [28]. Pseudo-first-order and pseudo-second-order kinetic models were used to analyze the kinetic data, as shown in Figure $7 b, c$. Correlation coefficients $R^{2}$ and reduced Chi-Sqr were adopted to evaluate these two models; a higher $\mathrm{R}^{2}$ and a lower reduced Chi-Sqr indicated a stronger degree of curve fitting [29]. Table 1 reveals that the pseudo-second-order kinetic model had higher values of $\mathrm{R}^{2}$ and lower values of reduced Chi-Sqr than the pseudo-first-order kinetic model. Furthermore, the equilibrium adsorption amounts of FSMAA calculated by the pseudo-second-order kinetic model were closer to the experimental values than those calculated by the pseudo-first-order kinetic model. Hence, the adsorption of MB onto FSMAA was better explained with the pseudo-second-order kinetic model. When the main mechanism of dye removal was electrostatic interaction, a similar result was also obtained in other dye adsorption kinetic researches [30-32].

To further investigate whether intraparticle diffusion was a speed control step in MB adsorption, intraparticle diffusion model was also adopted to analyze the kinetic data. As shown in Figure $7 \mathrm{~d}$ and Table 1 , all the fitting curves were composed of three parts and the rate constant $\left(k_{i}\right)$ of each part had a character of $k_{i, 1}>k_{i, 2}>k_{i, 3}$. Consequently, the adsorption process could be divided into three stages $[33,34]$. The first was immediate diffusion stage. A large number of MB molecules were adsorbed immediately from aqueous solution by functional groups grafted on the surface of FSMAA. The fact that the rate constant of FSMAA 2.0 was higher than those of FSMAA 1.5 and FSMAA 0.9 indicated more functional groups were introduced to the surface of adsorbent with the increase of 
grafted monomer concentration. The second was intraparticle diffusion stage. A small number of MB molecules occupying the adsorption sites on the surface of FSMAA diffused to the inner layer of FSMAA and were adsorbed in it. The rate constants in this stage were much lower than those in the first one. The last was equilibrium stage. The rate constants were close to zero. All the adsorbents achieved adsorption equilibrium after $90 \mathrm{~min}$. These results indicated that the surface adsorption was a rate-determining step and the intraparticle diffusion was a rate-influencing step in the adsorption of MB.
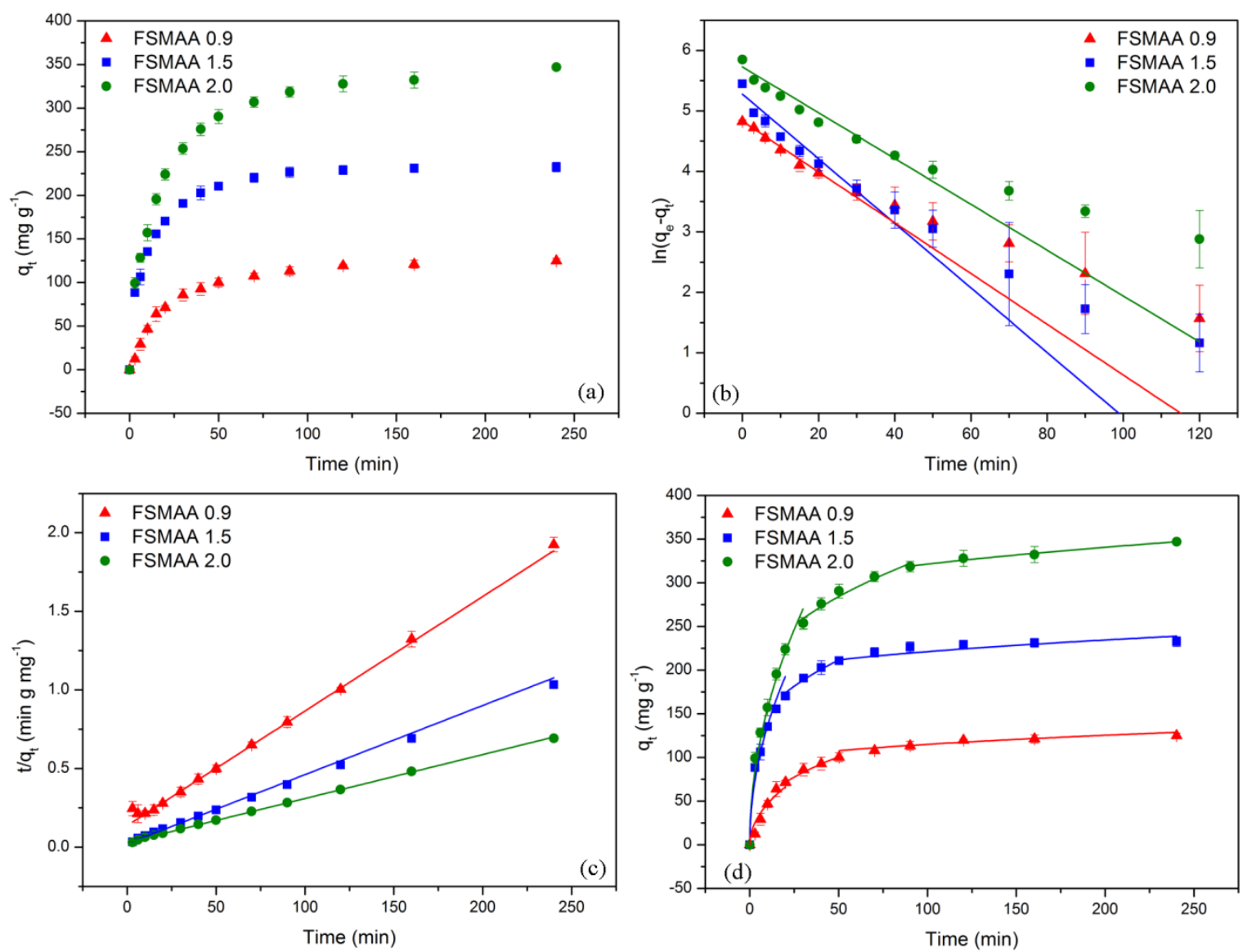

Figure 7. (a) Adsorption kinetics of MB adsorbed onto FSMAA; (b) fitting curves of pseudo-first-order kinetic model; (c) fitting curves of pseudo-second-order kinetic model; (d) fitting curves of intraparticle diffusion model. 
Table 1. Kinetic parameters for MB adsorption onto FSMAA ( $n=3$, Mean \pm SD).

\begin{tabular}{|c|c|c|c|c|c|c|c|c|c|c|c|c|}
\hline \multirow{3}{*}{$\begin{array}{c}\text { Monomer } \\
\text { Concentration } \\
\left(\mathrm{mol} \mathrm{L}^{-1}\right)\end{array}$} & \multirow{3}{*}{$\begin{array}{c}\mathrm{q}_{\mathrm{e}, \exp } \\
\left(\mathrm{mg} \mathrm{g}^{-1}\right)\end{array}$} & \multicolumn{4}{|c|}{ Pseudo-First-Order Model } & \multicolumn{4}{|c|}{ Pseudo-Second-Order Model } & \multicolumn{3}{|c|}{ Intraparticle Diffusion Model } \\
\hline & & \multirow{2}{*}{$\begin{array}{c}\mathrm{q}_{\mathrm{e} 1, \mathrm{cal}} \\
\left(\mathrm{mg} \mathrm{g}^{-1}\right)\end{array}$} & \multirow{2}{*}{$\begin{array}{l}\mathrm{k}_{1} \times 10^{2} \\
\left(\min ^{-1}\right)\end{array}$} & \multirow{2}{*}{$\mathbf{R}^{2}$} & \multirow{2}{*}{$\begin{array}{r}\text { Reduced } \\
\text { Chi-Sqr }\end{array}$} & \multirow{2}{*}{$\begin{array}{c}\mathrm{q}_{\mathrm{e} 2, \mathrm{cal}} \\
\left(\mathrm{mg} \mathrm{g}^{-1}\right)\end{array}$} & \multirow{2}{*}{$\begin{array}{c}k_{2} \times 10^{4} \\
\left(\mathrm{~g} \mathrm{mg}^{-1} \min ^{-1}\right)\end{array}$} & \multirow{2}{*}{$\mathbf{R}^{2}$} & \multirow{2}{*}{$\begin{array}{c}\text { Reduced } \\
\text { Chi-Sqr }\end{array}$} & $\mathbf{k}_{\mathrm{i}, 1}$ & $\mathbf{k}_{\mathrm{i}, 2}$ & $\mathbf{k}_{\mathrm{i}, 3}$ \\
\hline & & & & & & & & & & \multicolumn{3}{|c|}{$\left(\mathrm{mg} \mathrm{g}^{-1} \min ^{-1 / 2}\right)$} \\
\hline 0.9 & $124.8 \pm 3.0$ & $125.0 \pm 2.6$ & $4.20 \pm 0.32$ & 0.939 & 4.642 & $137.4 \pm 1.5$ & $3.84 \pm 0.16$ & 0.998 & 0.500 & $14.82 \pm 1.36$ & $11.20 \pm 0.60$ & $2.50 \pm 0.70$ \\
\hline 1.5 & $232.3 \pm 5.5$ & $195.7 \pm 13.2$ & $5.34 \pm 0.72$ & 0.832 & 14.218 & $227.3 \pm 4.0$ & $8.83 \pm 0.51$ & 0.996 & 8.888 & $43.10 \pm 2.86$ & $14.44 \pm 1.58$ & $3.22 \pm 0.60$ \\
\hline 2.0 & $346.8 \pm 3.0$ & $307.2 \pm 14.8$ & $3.79 \pm 0.50$ & 0.837 & 52.516 & $358.4 \pm 4.7$ & $2.56 \pm 0.15$ & 0.998 & 2.691 & $49.30 \pm 1.19$ & $15.69 \pm 1.64$ & $4.65 \pm 0.21$ \\
\hline
\end{tabular}




\subsubsection{Adsorption Isotherms}

The adsorption isotherms played an important role in understanding the interaction between adsorbents and adsorbates at specific temperatures and in estimating the adsorption mechanism. Three isothermal adsorption models were used to describe the adsorption process and the isothermal parameters of each model were calculated, as shown in Figure 8 and Table 2, respectively. The correlation coefficients $R^{2}$ of the Langmuir model $(\geq 0.929)$ were all higher than those of the Freundlich model $(\leq 0.884)$ and the D-R model $(\leq 0.919)$. Additionally, the reduced Chi-Sqr of the Langmuir model $\left(2.479 \times 10^{-7}, 5.762 \times 10^{-8}\right.$, and $2.704 \times 10^{-6}$ for FSMAA 0.9 , FSMAA 1.5, and FSMAA 2.0, respectively) were much lower than those of the Freundlich model $(0.028,0.038$, and 0.097 for FSMAA 0.9, FSMAA 1.5, and FSMAA 2.0, respectively) and the D-R model (0.013, 0.067 , and 0.048 for FSMAA 0.9 , FSMAA 1.5, and FSMAA 2.0, respectively). These phenomena indicated that the adsorption of MB onto FSMAA was better described by the Langmuir model. A dimensionless constant separation factor $\left(\mathrm{R}_{\mathrm{L}}\right)$ can be calculated by the Langmuir model, as shown in Equation (9).

$$
\mathrm{R}_{\mathrm{L}}=\frac{1}{1+\mathrm{K}_{\mathrm{L}} \times \mathrm{C}_{\mathrm{i}}}
$$
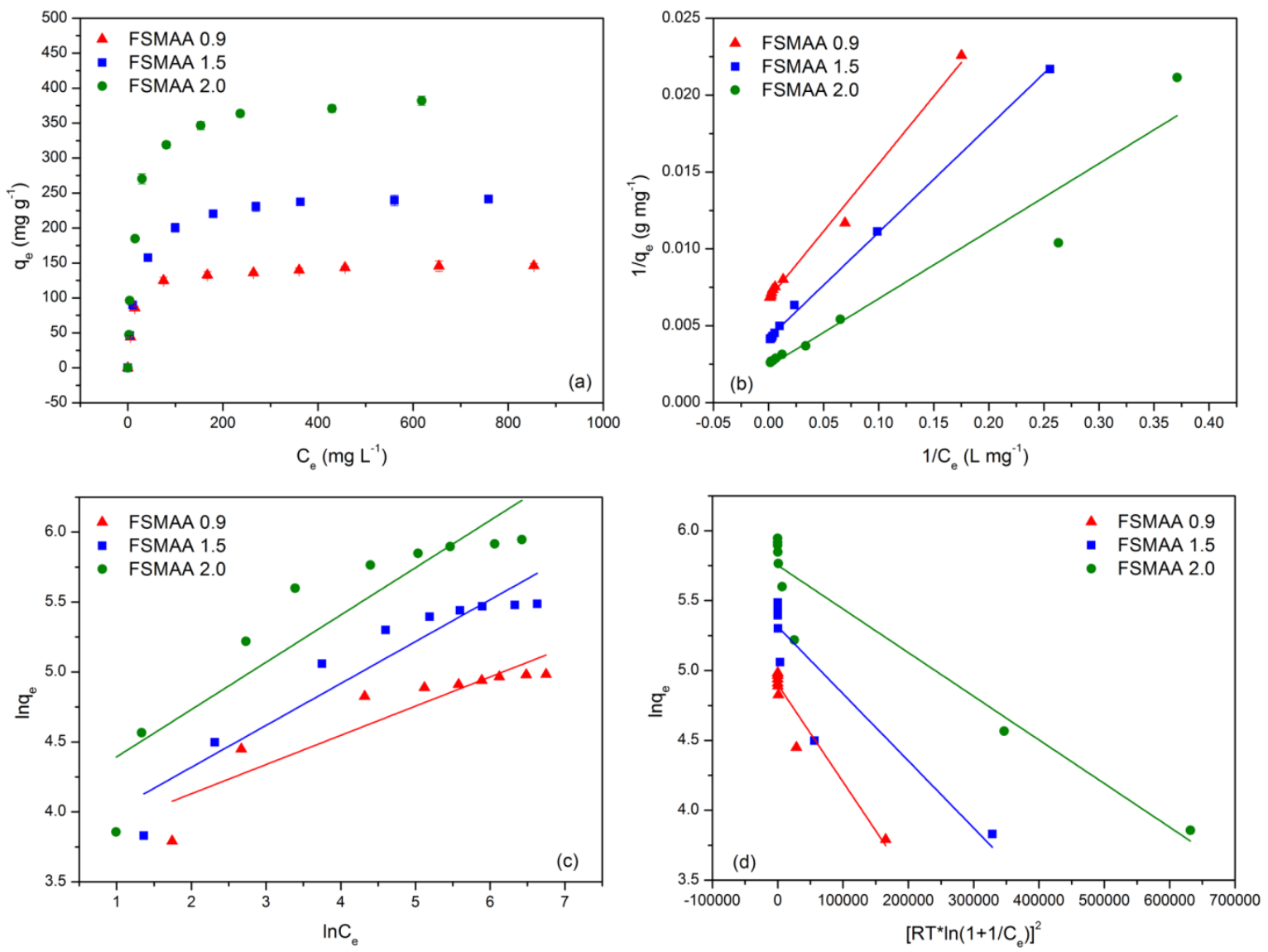

Figure 8. (a) Adsorption isotherms of MB adsorbed onto FSMAA; (b) fitting curves of Langmuir model; (c) fitting curves of Freundlich model; (d) fitting curves of D-R model.

$0<\mathrm{R}_{\mathrm{L}}<1$ implies a favorable adsorption, $\mathrm{R}_{\mathrm{L}}>1$ means an unfavorable adsorption, $\mathrm{R}_{\mathrm{L}}=0$ indicates an irreversible adsorption, and $\mathrm{R}_{\mathrm{L}}=1$ means a linear adsorption [35]. As seen in Figure 9 , $\mathrm{R}_{\mathrm{L}}$ values of FSMAA 0.9, FSMAA 1.5, and FSMAA 2.0 calculated from the Langmuir model were all smaller than 0.30 , demonstrating the adsorption of MB onto FSMAA was favorable. Furthermore, it 
was noted that $R_{L}$ values decreased as the initial concentrations of $M B$ were increased; this indicated a higher MB concentration was beneficial to adsorption.

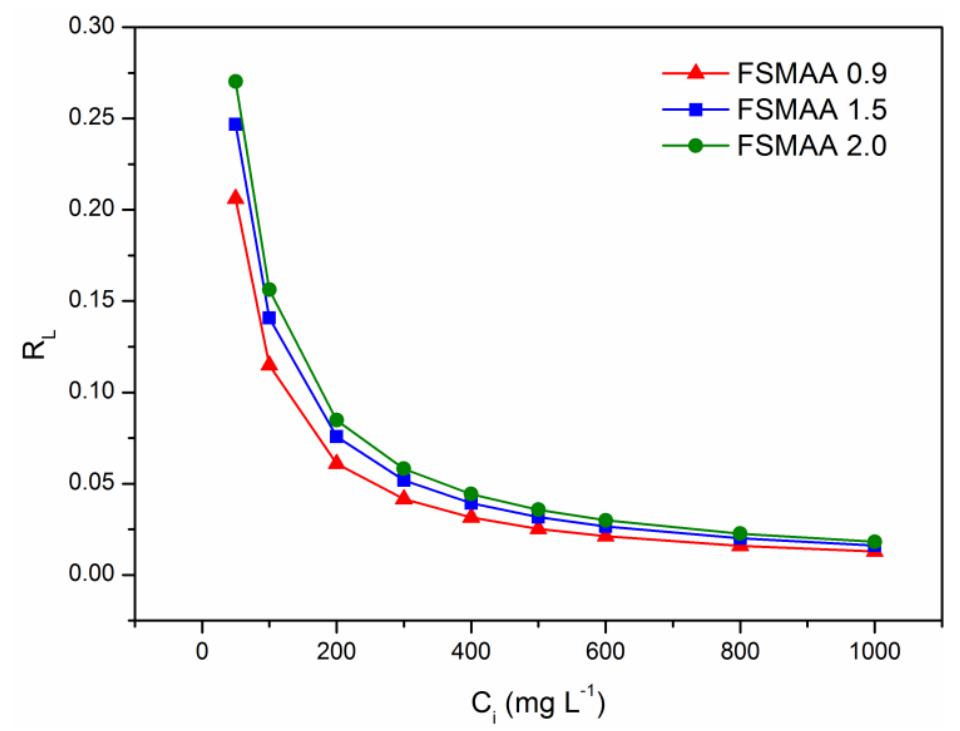

Figure 9. $\mathrm{R}_{\mathrm{L}}$ values of $\mathrm{MB}$ adsorbed onto FSMAA.

Besides, adsorption free energy $\left(E_{a}\right)$ was calculated according to the D-R model, as shown in Equation (10).

$$
\mathrm{E}_{\mathrm{a}}=\left(2 \mathrm{~K}_{\mathrm{D}}\right)^{-1 / 2}
$$

$\mathrm{E}_{\mathrm{a}}<8 \mathrm{~kJ} \mathrm{~mol}^{-1}$ implies a physical adsorption, $8 \mathrm{~kJ} \mathrm{~mol}^{-1}<\mathrm{E}_{\mathrm{a}}<16 \mathrm{~kJ} \mathrm{~mol}^{-1}$ means the adsorption mechanism is ion exchange, and $E_{a}>16 \mathrm{~kJ} \mathrm{~mol}^{-1}$ indicates a chemical adsorption [35]. In this work, $\mathrm{E}_{\mathrm{a}}$ values of FSMAA 0.9, FSMAA 1.5, and FSMAA 2.0 were $0.27,0.32$, and 0.40 , respectively.

As calculated by the Langmuir model, the maximum adsorption capacities of MB adsorbed onto FSMAA 0.9, FSMAA 1.5, and FSMAA 2.0 were $147.9 \mathrm{mg} \mathrm{g}^{-1}, 238.1 \mathrm{mg} \mathrm{g}^{-1}$, and $421.9 \mathrm{mg} \mathrm{g}^{-1}$, respectively. Table 3 lists the maximum adsorption capacities of FSMAA 2.0 and other adsorbents for MB. As can be seen, the adsorption capacity obtained in this study was much higher than those stated in previous literatures. This conclusion showed that self-made FSMAA had good potentiality in MB removal. 
Table 2. Isothermal parameters for MB adsorption onto FSMAA $(n=3$, Mean \pm SD).

\begin{tabular}{|c|c|c|c|c|c|c|c|c|c|c|c|c|}
\hline \multirow{2}{*}{$\begin{array}{c}\text { Monomer } \\
\text { Concentration } \\
\left(\mathrm{mol} \mathrm{L}^{-1}\right)\end{array}$} & \multicolumn{4}{|c|}{ Langmuir Model } & \multicolumn{4}{|c|}{ Freundlich Model } & \multicolumn{4}{|c|}{ D-R Model } \\
\hline & $\mathrm{q}_{\mathrm{m}}\left(\mathrm{mg} \mathrm{g}^{-1}\right)$ & $\mathrm{K}_{\mathrm{L}}\left(\mathrm{L} \mathrm{mg}^{-1}\right)$ & $\mathbf{R}^{2}$ & $\begin{array}{l}\text { Reduced } \\
\text { Chi-Sqr }\end{array}$ & $\mathbf{n}$ & $\mathrm{K}_{\mathrm{F}}$ & $\mathbf{R}^{2}$ & $\begin{array}{c}\text { Reduced } \\
\text { Chi-Sqr }\end{array}$ & $q_{D}\left(\mathrm{mg} \mathrm{g}^{-1}\right)$ & $\mathrm{K}_{\mathrm{D}}\left(\mathrm{mol}^{2} \mathrm{~kJ}^{-2}\right)$ & $\mathbf{R}^{2}$ & $\begin{array}{l}\text { Reduced } \\
\text { Chi-Sqr }\end{array}$ \\
\hline 0.9 & $147.9 \pm 4.2$ & $0.077 \pm 0.003$ & 0.991 & $2.479 \times 10^{-7}$ & $4.79 \pm 0.81$ & $40.95 \pm 7.36$ & 0.819 & 0.028 & $134.3 \pm 5.5$ & $6.97 \pm 0.73$ & 0.919 & 0.013 \\
\hline 1.5 & $238.1 \pm 5.2$ & $0.061 \pm 0.001$ & 0.998 & $5.762 \times 10^{-8}$ & $3.34 \pm 0.43$ & $41.28 \pm 7.76$ & 0.884 & 0.038 & $203.2 \pm 19.0$ & $4.80 \pm 0.84$ & 0.798 & 0.067 \\
\hline 2.0 & $421.9 \pm 19.4$ & $0.054 \pm 0.005$ & 0.929 & $2.704 \times 10^{-6}$ & $2.96 \pm 0.50$ & $57.73 \pm 14.19$ & 0.819 & 0.097 & $314.9 \pm 26.0$ & $3.12 \pm 0.34$ & 0.911 & 0.048 \\
\hline
\end{tabular}


Table 3. The maximum adsorption capacities of FSMAA 2.0 and other adsorbents for MB.

\begin{tabular}{|c|c|c|c|c|c|}
\hline Adsorbent & $\mathrm{pH}$ & $\begin{array}{c}\text { Temperature } \\
\text { (K) }\end{array}$ & $\begin{array}{c}\text { Equilibrium } \\
\text { Time (min) }\end{array}$ & $\begin{array}{c}\text { Adsorption } \\
\text { Capacity }\left(\mathrm{mg} \mathrm{g}^{-1}\right)\end{array}$ & Reference \\
\hline SNCM & 6.0 & 323 & 30 & 20.0 & [36] \\
\hline SW-ZnO-PANI & 7.0 & 305 & 100 & 20.6 & [37] \\
\hline GO-CS- $\mathrm{Fe}_{3} \mathrm{O}_{4}$ & 5.3 & 303 & 60 & 95.2 & [38] \\
\hline $\mathrm{Fe}_{3} \mathrm{O}_{4} / \mathrm{SiO}_{2}-\mathrm{GO}$ & N.A. ${ }^{a}$ & 333 & 70 & 111.1 & [39] \\
\hline $\mathrm{Fe}_{3} \mathrm{O}_{4} @ \mathrm{C} \mathrm{NPs}$ & 6.0 & 298 & 180 & 117.0 & [40] \\
\hline $\mathrm{GO}-\mathrm{Fe}_{3} \mathrm{O}_{4}$ & N.A. ${ }^{a}$ & 298 & 30 & 167.2 & [41] \\
\hline CS-Glu-MCMs & 7.0 & 293 & 5 & 182.5 & [22] \\
\hline MG-ILs-OH & 12.0 & 303 & 60 & 243.3 & [42] \\
\hline FSMAA 2.0 & 9.0 & 303 & 90 & 421.9 & This study \\
\hline
\end{tabular}

\subsubsection{Adsorption Mechanism}

Usually if an adsorption process was better described by the pseudo-second-order kinetic model, it was inferred to be a chemical one. However, as discussed in Section 3.2.4, the fact that $E_{a}$ calculated from the D-R model was lower than $8 \mathrm{~kJ} \mathrm{~mol}^{-1}$ implied the adsorption process should be a physical one. Hence, the adsorption mechanism in this study could not be simply classified as a chemical reaction or physical reaction rather, it was thought to be a combined one. Based on the results obtained in Section 3.2.3, the adsorption process was composed of surface adsorption, intraparticle diffusion adsorption, and equilibrium. Surface adsorption was the rate-determining step achieved by three types of interactions: (1) electrostatic interaction; (2) hydrogen bonding; and (3) hydrophobic interaction. Electrostatic interaction occurred between deprotonated groups (i.e., $-\mathrm{COO}^{-}$and $-\mathrm{SO}_{3}{ }^{-}$) on the surface of FSMAA and positively charged quaternary ammonium groups in MB. Hydrogen bonding referred to the interaction between $-\mathrm{OH},-\mathrm{NH}$ on the surface of FSMAA, and amine in MB [35,43]. Hydrophobic interaction was a tendency of nonpolar groups to associate in aqueous solution. Because of the aliphatic branches on its pendant groups, the grafted AMPS had a hydrophobic character and could react with benzene rings in $\mathrm{MB}$ through hydrophobic interaction $[44,45]$. The mechanism between MB and FSMAA in surface adsorption is schematically illustrated in Figure 10.

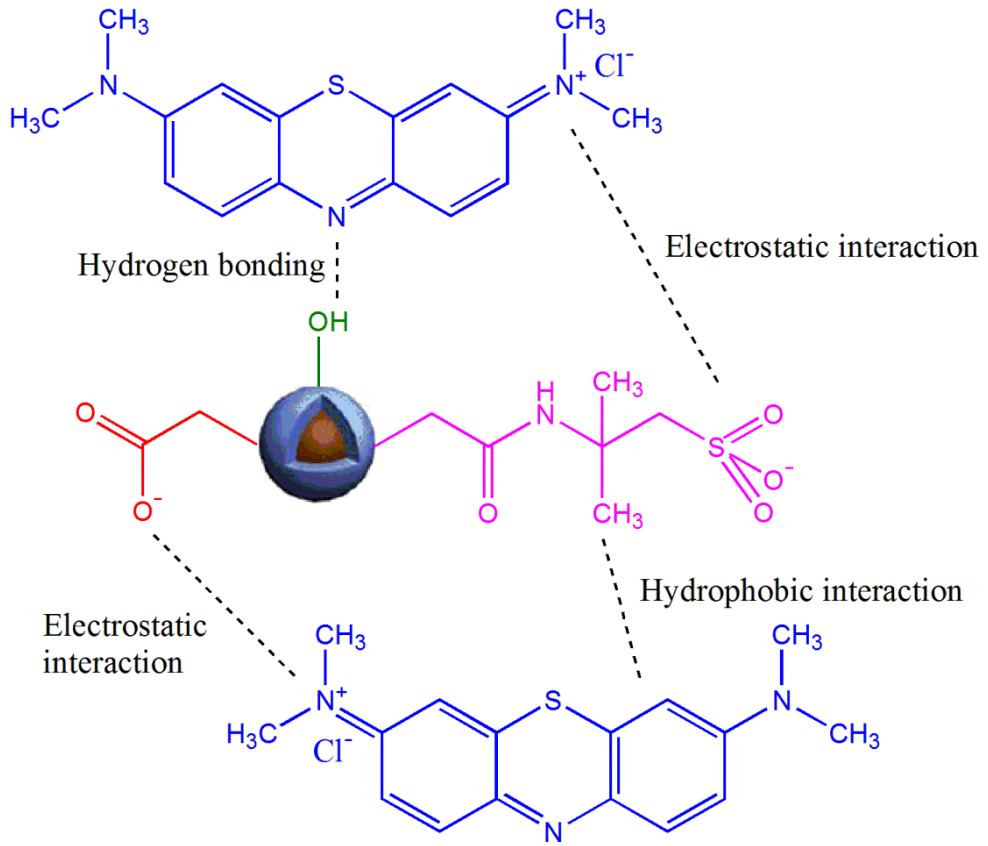

Figure 10. Schematic illustration of MB adsorbed onto FSMAA. 
Further evidence to support the above mechanism between MB and FSMAA was provided by XPS analysis. C1s and S2p XPS spectra of FSMAA before and after adsorption are shown in Figure 11, and the assignment, binding energy, and relative area percentage of peaks are summarized in Table 4. For the $\mathrm{C} 1 \mathrm{~s}$ spectra, three peaks at about $288 \mathrm{eV}, 286 \mathrm{eV}$, and $284 \mathrm{eV}$ corresponded to $\mathrm{C}=\mathrm{O}$, $\mathrm{C}-\mathrm{OH} / \mathrm{C}-\mathrm{N} / \mathrm{C}-\mathrm{S}$, and $\mathrm{C}-\mathrm{H} / \mathrm{C}-\mathrm{C}$, respectively. For the S2p spectra, peaks for $\mathrm{S}_{2} \mathrm{p}_{3 / 2}$ at $167.0-167.6 \mathrm{eV}$ and for $\mathrm{S}_{2} \mathrm{p}_{1 / 2}$ at $168.0-168.6 \mathrm{eV}$ were assigned to $\mathrm{S}=\mathrm{O}$. The relative area percentages of $\mathrm{C}=\mathrm{O}$ and $\mathrm{S}=\mathrm{O}$ decreased after adsorption, suggesting carboxyl and sulfonic acid groups were involved in the adsorption of MB onto FSMAA. The new peak at $285.1 \mathrm{eV}$ appearing in $\mathrm{C} 1 \mathrm{~s}$ spectrum after adsorption was attributed to the $\pi$ bond formed by the phenylalkane in adsorbed MB [46]. The new peaks at $163.7 \mathrm{eV}$ and $164.9 \mathrm{eV}$ for S2 $\mathrm{p}_{3 / 2}$ and S2 $\mathrm{p}_{1 / 2}$, respectively, in S2p spectrum after adsorption were also attributed to the adsorbed MB. The change of relative area percentage of each peak and the appearance of new peaks indicated that the functional groups on the surface of FSMAA reacted with MB through electrostatic interaction, hydrogen bonding, and hydrophobic interaction.
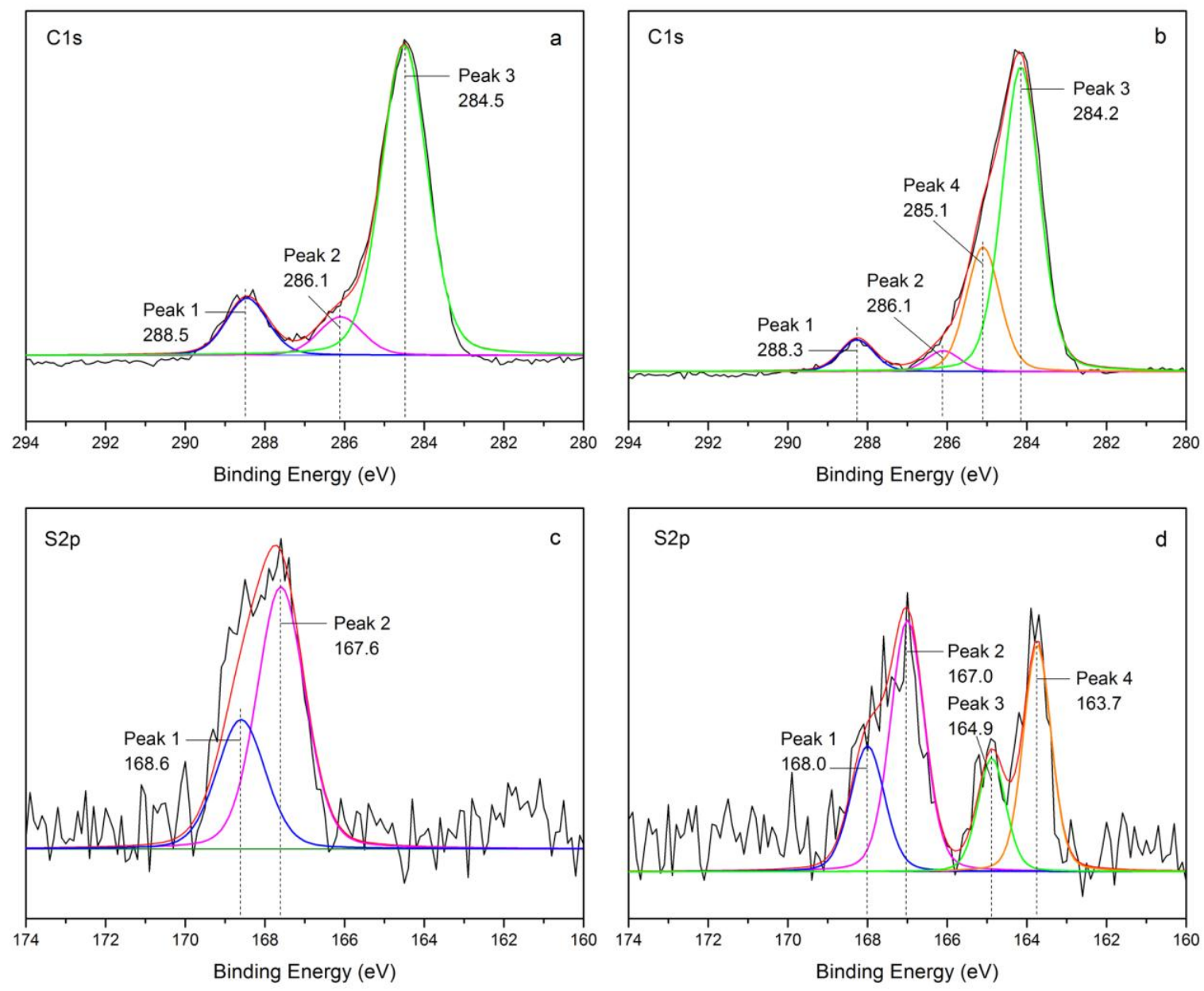

Figure 11. C1s and S2p XPS spectra of $(\mathbf{a}, \mathbf{c})$ FSMAA; (b,d) FSMAA-MB. 
Table 4. Normalized peak areas and assignments of XPS spectra.

\begin{tabular}{cccccccccc}
\hline \multirow{2}{*}{ Sample } & \multicolumn{4}{c}{ Peak for C1s Spectra } & \multicolumn{4}{c}{ Peak for S2p Spectra } \\
\cline { 3 - 9 } & Peak 1 & Peak 2 & Peak 3 & Peak 4 & Peak 1 & Peak 2 & Peak 3 & Peak 4 \\
\hline \multirow{2}{*}{ FSMAA } & BE $(\mathrm{eV})$ & 288.5 & 286.1 & 284.5 & - & 168.6 & 167.6 & - & - \\
& $\mathrm{RAP}(\%)$ & 13.04 & 9.26 & 77.70 & - & 33.33 & 66.67 & - & - \\
\hline \multirow{2}{*}{ FSMAA-MB } & $\mathrm{BE}(\mathrm{eV})$ & 288.3 & 286.1 & 284.2 & 285.1 & 168.0 & 167.0 & 164.9 & 163.7 \\
& $\mathrm{RAP}(\%)$ & 6.23 & 4.04 & 65.45 & 24.28 & 19.14 & 38.29 & 14.19 & 28.38 \\
\hline \multicolumn{2}{c}{ Assignment } & $\mathrm{C}=\mathrm{O}$ & $\mathrm{C}-\mathrm{OH} / \mathrm{C}-\mathrm{N} / \mathrm{C}-\mathrm{S}$ & $\mathrm{C}-\mathrm{H} / \mathrm{C}-\mathrm{C}$ & phenylalk-ane & $\mathrm{S}=\mathrm{O}$ & sulfoether/S-H \\
\hline
\end{tabular}

$\mathrm{BE}$ : binding energy; RAP: relative area percentage.

\subsection{Stability and Regeneration}

The adsorbent's stability and regeneration ability were important indexes in practical application. The stability of FSMAA in waters with different $\mathrm{pH}$ values was studied by measuring the leaching concentration of Fe. As illustrated in Figure 12a, the leaching of Fe was inhibited even in extremely acid environment (i.e., $\mathrm{pH}=0$ or 1 ) due to the protection of the outer polymer shell. This phenomenon demonstrated FSMAA had a good stability.
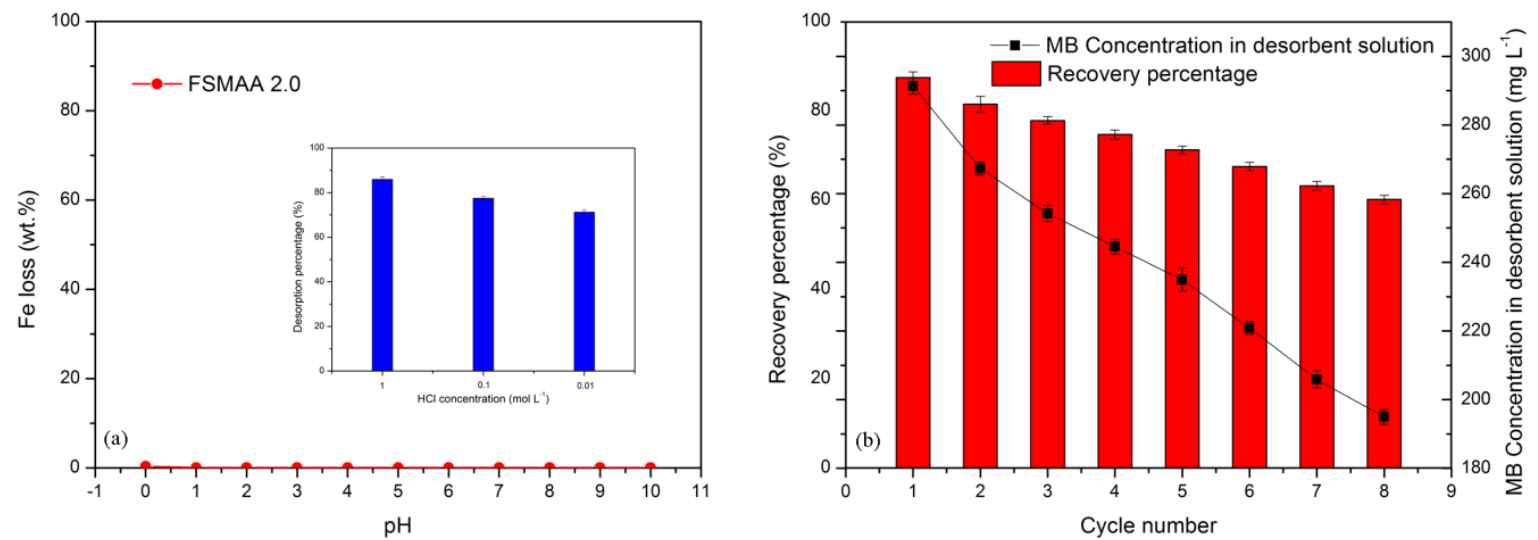

Figure 12. (a) Leaching of Fe from FSMAA in different $\mathrm{pH}$ solutions (the insert is the image of desorption percentages obtained by different desorbents); (b) recovery percentage of FSMAA and MB concentration in desorbent solution after every regeneration experiment in eight adsorption-regeneration cycles (grafted monomer concentration $=2.0 \mathrm{~mol} \mathrm{~L}^{-1}$ ).

As discussed in Section 3.2.2, the adsorption performance in acid environment was unsatisfactory. It was implied that acid pickling could be a feasible way to regenerate the adsorbent [47]. Hence, $1 \mathrm{~mol} \mathrm{~L}^{-1}, 0.1 \mathrm{~mol} \mathrm{~L}^{-1}$, and $0.01 \mathrm{~mol} \mathrm{~L}^{-1} \mathrm{HCl}$ were adopted as the desorbents and the desorption performance is shown in the insert of Figure 12a. The desorption percentages for $1 \mathrm{~mol} \mathrm{~L}^{-1}, 0.1 \mathrm{~mol} \mathrm{~L}^{-1}$, and $0.01 \mathrm{~mol} \mathrm{~L}^{-1} \mathrm{HCl}$ were $85.9 \%, 77.5 \%$, and $71.2 \%$, respectively, so $1 \mathrm{~mol} \mathrm{~L}^{-1} \mathrm{HCl}$ was chosen as the desorbent for the adsorption-regeneration experiments. As seen in Figure 12b, the recovery percentage of FSMAA and the MB concentration in desorbent solution after every regeneration experiment declined with the increase of cycle number. This was probably caused by the decrease of adsorbent quantity and the incomplete desorption of $\mathrm{MB}$ adsorbed at the bottom of grafted polymer chains. Nevertheless, the remaining adsorption capacity was more than $60 \%$ after eight adsorption-regeneration cycles, indicating FSMAA had a good regeneration ability.

\section{Conclusions}

Polymer-functionalized MNPs named FSMAA were successfully synthesized by grafting AA and AMPS on the surface of $\mathrm{Fe}_{3} \mathrm{O}_{4} @ \mathrm{SiO}_{2}$-MPS through one-pot free radical polymerization. Various characterization techniques, including TEM, FTIR, XRD, XPS, and VSM, had been used and it was 
confirmed that the obtained FSMAA had a core-shell structure, a good magnetic property, and plenty of functional groups on its surface. MB adsorption experiments showed that the adsorption capacity of FSMAA increased with the increase of grafted monomer concentration and solution $\mathrm{pH}$. The experimental kinetic data were well described by the pseudo-second-order kinetic model and the adsorption equilibrium was achieved after $90 \mathrm{~min}$. Besides, the intraparticle diffusion model proved the adsorption process contained three stages. The experimental isothermal data were better explained by the Langmuir model and the maximum adsorption capacity of FSMAA 2.0 calculated from this model was $421.9 \mathrm{mg} \mathrm{g}^{-1}$, much higher than those of other adsorbents stated in previous literatures. The excellent adsorption performance was attributed to the electrostatic interaction, hydrogen bonding, and hydrophobic interaction. Furthermore, FSMAA exhibited a good stability and regeneration ability; the remaining adsorption capacity was more than $60 \%$ after eight adsorption-regeneration cycles. All the above mentioned indicated FSMAA's potentiality of practical application in the removal of MB from wastewater. Our future work will be more concentrated on the mechanism analysis (for example, the grafting reaction studies and thermodynamic studies) and the further optimization of other synthesis conditions (for example, the amounts of added TEOS and MPS).

Author Contributions: Data curation, X.Z., R.Z., and Q.S.; formal analysis, X.Z., R.Z., and S.Z.; funding acquisition, H.Z.; investigation, X.Z., R.Z., Q.S., S.Z., and Yongzhi Liu; methodology, X.Z.; project administration, H.Z. and Y.S.; writing-original draft, X.Z.; writing-review \& editing, H.Z. and Y.S.

Funding: This research was funded by the National Natural Science Foundation of China (Project No. 21677020) and 111 Project (Project No. B13041).

Acknowledgments: The authors are grateful for the financial support provided by the National Natural Science Foundation of China (Project No. 21677020) and 111 Project (Project No. B13041).

Conflicts of Interest: The authors declare no conflict of interest.

\section{References}

1. Wen, S.; Gao, B.; Xing, X.; Xing, L.; Shuang, H.; Duan, P.; Song, W.; Jia, R. Adsorption-desorption behavior of magnetic amine $/ \mathrm{Fe}_{3} \mathrm{O}_{4}$ functionalized biopolymer resin towards anionic dyes from wastewater. Bioresour. Technol. 2016, 210, 123-130.

2. Bibi, I.; Bhatti, H.N.; Asgher, M. Decolourisation of direct dyes with manganese peroxidase from white rot basidiomycete Ganoderma lucidum IBL-5. Can. J. Chem. Eng. 2009, 87, 435-440. [CrossRef]

3. Yang, C.X.; Lei, L.; Zhou, P.X.; Zhang, Z.; Lei, Z.Q. Preparation and characterization of poly(AA co PVP)/PGS composite and its application for methylene blue adsorption. J. Colloid Interface Sci. 2015, 443, 97-104. [CrossRef] [PubMed]

4. Singh, J.; Chang, Y.Y.; Koduru, J.R.; Yang, J.K. Potential degradation of methylene blue (MB) by nano-metallic particles: A kinetic study and possible mechanism of MB degradation. Environ. Eng. Res. 2018, 23, 1-9. [CrossRef]

5. Spagnoli, A.A.; Giannakoudakis, D.A.; Bashkova, S. Adsorption of methylene blue on cashew nut shell based carbons activated with zinc chloride: The role of surface and structural parameters. J. Mol. Liq. 2017, 229, 465-471. [CrossRef]

6. Yang, M.; Liu, X.; Qi, Y.; Sun, W.; Men, Y. Preparation of K-carrageenan/graphene oxide gel beads and their efficient adsorption for methylene blue. J. Colloid Interface Sci. 2017, 506, 669-677. [CrossRef] [PubMed]

7. Barroso-Martín, I.; Moretti, E.; Talon, A.; Storaro, L.; Rodríguez-Castellón, E.; Infantes-Molina, A. Au and $\mathrm{AuCu}$ nanoparticles supported on SBA-15 ordered mesoporous titania-silica as catalysts for methylene blue photodegradation. Materials 2018, 11, 890-906. [CrossRef] [PubMed]

8. Singh, J.; Yang, J.K.; Chang, Y.Y.; Koduru, J.R. Fenton-like degradation of methylene blue by ultrasonically dispersed nano zero-valent metals. Environ. Process. 2017, 4, 169-182. [CrossRef]

9. Zhao, F.; Liu, L.; Yang, F.; Ren, N. E-Fenton degradation of MB during filtration with Gr/PPy modified membrane cathode. Chem. Eng. J. 2013, 230, 491-498. [CrossRef]

10. Saaidia, S.; Delimi, R.; Benredjem, Z.; Mehellou, A.; Djemel, A.; Barbari, K. Use of a $\mathrm{PbO}_{2}$ electrode of a lead-acid battery for the electrochemical degradation of methylene blue. Sep. Sci. 2017, 52, 1602-1614. [CrossRef] 
11. Abbasi, M. Synthesis and characterization of magnetic nanocomposite of chitosan $/ \mathrm{SiO}_{2} /$ carbon nanotubes and its application for dyes removal. J. Clean. Prod. 2017, 145, 105-113. [CrossRef]

12. Lu, A.H.; Salabas, E.L.; Schüth, F. Magnetic nanoparticles: Synthesis, protection, functionalization, and application. Angew. Chem. Int. Ed. 2007, 46, 1222-1244. [CrossRef] [PubMed]

13. Ge, Y.; Li, Y.; Zu, B.; Zhou, C.; Dou, X. AM-DMC-AMPS multi-functionalized magnetic nanoparticles for efficient purification of complex multiphase water system. Nanoscale Res. Lett. 2016, 11, 217-225. [CrossRef] [PubMed]

14. Javaheri, F.; Hassanajili, S. Synthesis of $\mathrm{Fe}_{3} \mathrm{O}_{4} @ \mathrm{SiO}_{2} @ \mathrm{MPS} @ P 4 V P$ nanoparticles for nitrate removal from aqueous solutions. J. Appl. Polym. Sci. 2016, 133, 44330. [CrossRef]

15. Li, K.; Wang, Y.; Huang, M.; Yan, H.; Yang, H.; Xiao, S.; Li, A. Preparation of chitosan-graft-polyacrylamide magnetic composite microspheres for enhanced selective removal of mercury ions from water. J. Colloid Interface Sci. 2015, 455, 261-270. [CrossRef] [PubMed]

16. Pan, M.; Sun, Y.; Zheng, J.; Yang, W. Boronic acid-functionalized core-shell-shell magnetic composite microspheres for the selective enrichment of glycoprotein. ACS Appl. Mater. Interfaces 2013, 5, 8351-8358. [CrossRef] [PubMed]

17. Mostafaei, M.; Hosseini, S.N.; Khatami, M.; Javidanbardan, A.; Sepahy, A.A.; Asadi, E. Isolation of recombinant Hepatitis B surface antigen with antibody-conjugated superparamagnetic $\mathrm{Fe}_{3} \mathrm{O}_{4} / \mathrm{SiO}_{2}$ core-shell nanoparticles. Protein Expr. Purif. 2018, 145, 1-6. [CrossRef] [PubMed]

18. Li, C.; Lu, J.; Li, S.; Tong, Y.; Ye, B. Synthesis of magnetic microspheres with sodium alginate and activated carbon for removal of methylene blue. Materials 2017, 10, 84-97. [CrossRef] [PubMed]

19. Park, H.S.; Koduru, J.R.; Choo, K.H.; Lee, B. Activated carbons impregnated with iron oxide nanoparticles for enhanced removal of bisphenol A and natural organic matter. J. Hazard. Mater. 2015, 286, 315-324. [CrossRef] [PubMed]

20. Yuan, Q.; Li, N.; Chi, Y.; Geng, W.; Yan, W.; Zhao, Y.; Li, X.; Dong, B. Effect of large pore size of multifunctional mesoporous microsphere on removal of heavy metal ions. J. Hazard. Mater. 2013, 254, 157-165. [CrossRef] [PubMed]

21. Cao, N.; Zhao, Y.; Sang, B.; Wang, Z.; Cao, L.; Sun, L.; Zou, X. Fabrication of autofluorescent porous silica nanoparticles for redox-responsive drug release. Mater. Sci. Eng. C 2016, 69, 330-336. [CrossRef] [PubMed]

22. Yan, H.; Li, H.; Yang, H.; Li, A.; Cheng, R. Removal of various cationic dyes from aqueous solutions using a kind of fully biodegradable magnetic composite microsphere. Chem. Eng. J. 2013, 223, 402-411. [CrossRef]

23. Chang, M.; Lin, W.S.; Xiao, W.; Chen, Y.N. Antibacterial effects of magnetically-controlled $\mathrm{Ag} / \mathrm{Fe}_{3} \mathrm{O}_{4}$ nanoparticles. Materials 2018, 11, 659-666. [CrossRef] [PubMed]

24. Liao, Y.; Zheng, X.; Zhang, Z.; Xu, B.; Sun, Y.; Liu, Y.; Zheng, H. Ultrasound-assisted polymerization of $\mathrm{P}(\mathrm{AM}-\mathrm{DMDAAC})$ : Synthesis, characterization and sludge dewatering performance. J. Environ. Chem. Eng. 2017, 5, 5439-5447. [CrossRef]

25. Ma, J.; Jia, Y.; Jing, Y.; Yao, Y.; Sun, J. Kinetics and thermodynamics of methylene blue adsorption by cobalt-hectorite composite. Dyes Pigment. 2012, 93, 1441-1446. [CrossRef]

26. Yu, B.; He, L.; Wang, Y.; Cong, H. Multifunctional PMMA@ $\mathrm{Fe}_{3} \mathrm{O}_{4} @ \mathrm{DR}$ magnetic materials for efficient adsorption of dyes. Materials 2017, 10, 1239-1250. [CrossRef] [PubMed]

27. Lingamdinne, L.P.; Koduru, J.R.; Choi, Y.L.; Chang, Y.Y.; Yang, J.K. Studies on removal of Pb(II) and Cr(III) using graphene oxide based inverse spinel nickel ferrite nano-composite as sorbent. Hydrometallurgy 2016, 165, 64-72. [CrossRef]

28. Lingamdinne, L.P.; Chang, Y.Y.; Yang, J.K.; Singh, J.; Choi, E.H.; Shiratani, M.; Koduru, J.R.; Attri, P. Biogenic reductive preparation of magnetic inverse spinel iron oxide nanoparticles for the adsorption removal of heavy metals. Chem. Eng. J. 2017, 307, 74-84. [CrossRef]

29. Wang, T.; Stewart, C.E.; Ma, J.; Zheng, J.; Zhang, X. Applicability of five models to simulate water infiltration into soil with added biochar. J. Arid Land 2017, 9, 701-711. [CrossRef]

30. Long, Y.; Xiao, L.; Cao, Q. Co-polymerization of catechol and polyethylenimine on magnetic nanoparticles for efficient selective removal of anionic dyes from water. Powder Technol. 2017, 310, 24-34. [CrossRef]

31. Dai, Y.; Zou, J.; Liu, D.; Niu, L.; Zhou, L.; Zhou, Y.; Zhang, X. Preparation of Congo red functionalized $\mathrm{Fe}_{3} \mathrm{O}_{4} @ \mathrm{SiO}_{2}$ nanoparticle and its application for the removal of methylene blue. Colloids Surf. A 2018, 550, 90-98. 
32. Wang, P.; Wang, X.; Yu, S.; Zou, Y.; Wang, J.; Chen, Z.; Alharbi, N.S.; Alsaedi, A.; Hayat, T.; Chen, Y. Silica coated $\mathrm{Fe}_{3} \mathrm{O}_{4}$ magnetic nanospheres for high removal of organic pollutants from wastewater. Chem. Eng. J. 2016, 306, 280-288. [CrossRef]

33. Hao, Y.M.; Man, C.; Hu, Z.B. Effective removal of $\mathrm{Cu}$ (II) ions from aqueous solution by amino-functionalized magnetic nanoparticles. J. Hazard. Mater. 2010, 184, 392-399. [CrossRef] [PubMed]

34. Repo, E.; Warchol, J.K.; Kurniawan, T.A.; Sillanpää, M.E.T. Adsorption of Co(II) and Ni(II) by EDTA- and/or DTPA-modified chitosan: Kinetic and equilibrium modeling. Chem. Eng. J. 2010, 161, 73-82. [CrossRef]

35. Fan, S.; Tang, J.; Wang, Y.; Li, H.; Zhang, H.; Tang, J.; Wang, Z.; Li, X. Biochar prepared from co-pyrolysis of municipal sewage sludge and tea waste for the adsorption of methylene blue from aqueous solutions: Kinetics, isotherm, thermodynamic and mechanism. J. Mol. Liq. 2016, 220, 432-441. [CrossRef]

36. Mokhtar, M. Application of synthetic layered sodium silicate magadiite nanosheets for environmental remediation of methylene blue dye in water. Materials 2017, 10, 760-772. [CrossRef] [PubMed]

37. Pandimurugan, R.; Thambidurai, S. Synthesis of seaweed-ZnO-PANI hybrid composite for adsorption of methylene blue dye. J. Environ. Chem. Eng. 2016, 4, 1332-1347. [CrossRef]

38. Fan, L.; Luo, C.; Li, X.; Lu, F.; Qiu, H.; Sun, M. Fabrication of novel magnetic chitosan grafted with graphene oxide to enhance adsorption properties for methyl blue. J. Hazard. Mater. 2012, 215-216, 272-279. [CrossRef] [PubMed]

39. Yao, Y.; Miao, S.; Yu, S.; Ma, L.P.; Sun, H.; Wang, S. Fabrication of $\mathrm{Fe}_{3} \mathrm{O}_{4} / \mathrm{SiO}_{2}$ core / shell nanoparticles attached to graphene oxide and its use as an adsorbent. J. Colloid Interface Sci. 2012, 379, 20-26. [CrossRef] [PubMed]

40. Wu, R.; Liu, J.H.; Zhao, L.; Zhang, X.; Xie, J.; Yu, B.; Ma, X.; Yang, S.T.; Wang, H.; Liu, Y. Hydrothermal preparation of magnetic $\mathrm{Fe}_{3} \mathrm{O}_{4} @ \mathrm{C}$ nanoparticles for dye adsorption. J. Environ. Chem. Eng. 2014, 2, 907-913. [CrossRef]

41. Xie, G.; Xi, P.; Liu, H.; Chen, F.; Huang, L.; Shi, Y.; Hou, F.; Zeng, Z.; Shao, C.; Wang, J. A facile chemical method to produce superparamagnetic graphene oxide- $\mathrm{Fe}_{3} \mathrm{O}_{4}$ hybrid composite and its application in the removal of dyes from aqueous solution. J. Mater. Chem. 2011, 22, 1033-1039. [CrossRef]

42. Li, L.; Liu, F.; Duan, H.; Wang, X.; Li, J.; Wang, Y.; Luo, C. The preparation of novel adsorbent materials with efficient adsorption performance for both chromium and methylene blue. Colloids Surf. B 2016, 141, 253-259. [CrossRef] [PubMed]

43. Wang, F.; Zhang, L.; Wang, Y.; Liu, X.; Rohani, S.; Lu, J. Fe $\mathrm{O}_{4} @ \mathrm{SiO}_{2} @ C S-T E T A$ functionalized graphene oxide for the adsorption of methylene blue (MB) and Cu(II). Appl. Surf. Sci. 2017, 420, 970-981. [CrossRef]

44. Moreno-Villoslada, I.; Torres, C.; González, F.; Shibue, T.; Nishide, H. Binding of methylene blue to polyelectrolytes containing sulfonate groups. Macromol. Chem. Phys. 2009, 210, 1167-1175. [CrossRef]

45. Wu, Z.; You, L.; Xiang, H.; Jiang, Y. Comparison of dye adsorption by mesoporous hybrid gels: Understanding the interactions between dyes and gel surfaces. J. Colloid Interface Sci. 2006, 303, 346-352. [CrossRef] [PubMed]

46. Liu, B.; Chen, X.; Zheng, H.; Wang, Y.; Sun, Y.; Zhao, C.; Zhang, S. Rapid and efficient removal of heavy metal and cationic dye by carboxylate-rich magnetic chitosan flocculants: Role of ionic groups. Carbohydr. Polym. 2018, 181, 327-336. [CrossRef] [PubMed]

47. Yang, S.; Zong, P.; Ren, X.; Wang, Q.; Wang, X. Rapid and high-efficient preconcentration of Eu(III) by core-shell structured $\mathrm{Fe}_{3} \mathrm{O}_{4} @$ humic acid magnetic nanoparticles. ACS Appl. Mater. Interfaces 2012, 4, 6891-6900. [CrossRef] [PubMed]

(C) 2018 by the authors. Licensee MDPI, Basel, Switzerland. This article is an open access article distributed under the terms and conditions of the Creative Commons Attribution (CC BY) license (http:/ / creativecommons.org/licenses/by/4.0/). 